Scholarship Repository

University of Minnesota Law School

Articles

Faculty Scholarship

1997

\title{
Gender, Race, and Sentencing
}

Kathleen Daly

Michael Tonry

University of Minnesota Law School, tonry001@umn.edu

Follow this and additional works at: https://scholarship.law.umn.edu/faculty_articles

Part of the Law Commons

\section{Recommended Citation}

Kathleen Daly and Michael Tonry, Gender, Race, and Sentencing, 22 CRIME \& JUST. 201 (1997), available at https://scholarship.law.umn.edu/faculty_articles/487.

This Article is brought to you for free and open access by the University of Minnesota Law School. It has been accepted for inclusion in the Faculty Scholarship collection by an authorized administrator of the Scholarship Repository. For more information, please contact lenzx009@umn.edu. 


\section{Katbleen Daly and Michael Tonry}

\section{Gender, Race, and Sentencing}

\section{A B S T RA C T}

Race and gender pose empirical and policy problems that are both similar and different for the U.S. criminal justice system. They are similar in that blacks and women occupy subordinate social and economic positions in American life, and their interests are less likely to be represented in the justice system than are those of white men. They are different in that blacks are overrepresented in arrest statistics and jail and prison populations while women are underrepresented. If over- (or under-) representation is assumed to result from similar effects of bias and subordination, the two patterns are hard to explain. The empirical literature on criminal courts reveals policy dilemmas in achieving "just" sentencing practices. Blacks (and especially black men) may be more likely than white men or women to benefit from tightly limited discretion and limited individualization of sentencing whereas women (both black and white) may be more likely to benefit from broader discretion and greater individualization. Future policies will need to confront the competing demands of justice that race and gender pose in the official response to crime.

On June 30, 1995, federal and state prisons in the United States held $1,104,074$ sentenced prisoners. Black men and women, who are 12 percent of the general population, were 51 percent of prisoners. Women of all racial and ethnic groups, who are 51 percent of the general population, were 6 percent (Bureau of Justice Statistics 1995b).

Racial and ethnic disproportionalities in those charged, convicted,

Kathleen Daly is associate professor, School of Justice Administration, Faculty of $\mathrm{Hu}$ manities, Griffith University, Queensland, Australia. Michael Tonry is Sonosky Professor of Law and Public Policy, University of Minnesota Law School.

(C) 1997 by The University of Chicago. All rights reserved.

$0192-3234 / 97 / 0022-0006 \$ 02.00$ 
and sentenced for crime in the United States have received renewed attention in recent years. Reports by The Sentencing Project, which showed that in 1990 and 1995, respectively, 23 and 32 percent of black men aged twenty to twenty-nine were in jail or prison or on probation or parole, received front-page attention in newspapers and electronic media. So did estimates from the National Center on Institutions and Alternatives, which showed that in 1991 in Baltimore and Washington, D.C., respectively, 56 and 42 percent of black men aged eighteen to thirty-five were under some form of criminal justice system control (Tonry and Hamilton 1997).

Gender disproportionalities, while receiving relatively less media or political attention, are as great as or greater than those for race. For example, in 1995 the male incarceration rate for state and federal prisons, 789 per 100,000 , was sixteen times the female rate of 47 per 100,000 . In 1993, the black incarceration rate, 1,471 per 100,000 , was seven times the white rate of 207 per 100,000 (Bureau of Justice Statistics 1995a, 1995b).

At every stage of the justice system for which national data are available, the 51 percent of Americans who are female make up 6-14 percent of those prosecuted or confined in adult institutions. By contrast, the 12 percent of Americans who are black make up 40-54 percent of court and confinement populations. For example, the female share of convictions in state felony courts in 1990 was 14 percent; the black share, 47 percent (Bureau of Justice Statistics 1993a, p. 16). ${ }^{1}$ The female share of jail inmates in 1994 was 10 percent; the black share, 44 percent (Bureau of Justice Statistics 1995c). The female share of new court commitments to prisons in 1991 was 9 percent; the black share, 54 percent (Maguire and Pastore 1994, p. 625). Just over 1 percent of those on death row in 1993 were female; 41 percent were black (Bureau of Justice Statistics $1994 d$, table 6). ${ }^{2}$

These data suggest distinctive influences of gender and race on patterns of lawbreaking and on the state's response to crime, yet racism and sexism are often decried in the same sentence as variants of the same problem: white men's social, economic, and political dominance over less powerful women and minority group men. This has led some to adopt the simple working hypothesis of racial and gender discrimi-

\footnotetext{
${ }^{1}$ The black/white composition of felony court defendants varies by the source of data used (discussed below).

${ }^{2}$ An additional 8 percent were Hispanic.
} 
nation: institutions of criminal justice operate in ways that favor the interests of whites over blacks (or other minority groups) and of men over women.

The cross-sectional data portray a more complicated pattern. Race operates as the hypothesis predicts: blacks are overrepresented in arrest, court, and prison populations. But women, members of the socially subordinate gender group, are underrepresented in arrest, court, and prison populations. Although the hypothesis holds witbin gender groups - that is, among both male and female prisoners, 65 percent are members of racial or ethnic minority groups (Bureau of Justice Statistics $1995 a$, p. 9)-it cannot explain the disproportionate presence of men under formal criminal justice control.

The demography of crime and punishment poses challenges to feminist and nonfeminist explanations of crime and punishment. Feminist theorists have yet to explain why, if men have more power than women, men are at greater risk to be under criminal justice control. Nonfeminist theorists have yet to explain why, if disadvantaged members of society are most likely to be under criminal justice control, far fewer disadvantaged women than disadvantaged men are affected. ${ }^{3}$

This essay reviews race and gender patterns in adult arrest and imprisonment statistics, but our focus is on the criminal courts and the transformation of sentencing policy in the 1970s. We are interested in understanding why sentencing reform unfolded as it did and with what consequences for contemporary justice system practices, including dramatic increases in imprisonment for members of all race and gender groups. We are also interested in the varied ways that race and gender work in the criminal process and in criminological discourse.

Sentencing and its reform can be seen as one component of a criminal justice system that operates as a "social ordering practice" (Garland 1990; Lacey 1994, pp. 28-35). Sentencing, and punishment more generally, contain symbolic and instrumental elements. The justice system produces a good deal of injustice, but some of its elements are positive, indeed indispensable. Moreover, the rhetoric of sentencing reform must be set alongside the practices: the two do not necessarily coincide. For example, the rhetorical focus of sentencing reform in the 1970 s was on "just deserts," but utilitarian considerations could not be

\footnotetext{
${ }^{3}$ This claim is contextual (i.e., within a neighborhood or city) and historically and culturally specific. It would be wrong to assume that women are (or will be) more lawabiding than men (or less likely to be criminalized) across time, place, nation, and culture.
} 
avoided or eliminated. The story of sentencing reform was (and is) partly about "doing justice" better and partly about relegitimating the state's power to punish in a society rife with "background conditions of inequality and injustice" (Lacey 1994, p. 33).

Beginning in the early 1970s and with the stated aim of reducing race and class disparities in the justice system, sentencing reformers advocated strong equality policies, often expressed in terms of "just deserts" or proportionality theories that emphasized the current offense and the defendant's criminal history as the primary criteria for sentencing. The central rationale was that the broad discretionary power permitted in indeterminate sentencing systems was exercised in ways unfavorable to poor and minority defendants; in particular, by allowing officials to take into account a defendant's biographical information (e.g., education, employment prospects, and familial circumstances), it was believed that white and middle-class defendants were advantaged over others.

Throughout the debates on sentencing reform, the presumptive sentencing subject was male: women and gender differences were not featured. What might explain this silence? First, like their academic counterparts, criminal justice policy makers would argue that "there were too few women" to warrant inquiry on the gendered dynamics of crime and crime control. This seems curious in that men are no less gendered than women. However, because women are the marked gender category, when the question of "gender" enters criminological discourse, attention centers on "women's issues" or "the female offender." As the unmarked gender category, men are "the norm," the universal nongendered offender. Second, in feminist criminological and legal inquiry, and in feminist activism during the 1970s and 1980s, attention was paid primarily to violence against women. By contrast, research on women's lawbreaking and its response were (and remain) less developed. Third, even for those with research and policy interests in gender, courts, and prisons, it was difficult to know bow to engage in policy debates; it was not clear what to recommend. ${ }^{4}$

The early sentencing reform movement in the United States emerged from a race-centered civil rights movement and from the prisoners' rights movement that began in the 1960s (e.g., American

\footnotetext{
${ }^{4}$ Examples of dilemmas and ambivalences surrounding feminist engagement with criminal justice are given by Chesney-Lind (1991), on whether to push for building a women's prison or not, and by Daly (1992) and Howe (1990) on how to represent women lawbreakers and prisoners.
} 
Friends Service Committee 1971; Messinger and Johnson 1978). During 1965 to 1975 , 96-97 percent of prisoners were men, and approximately 40 percent were black. Sentencing became the object of reformers' attention not only because of widespread interest in sentencing processes per se but because of concern for racial injustices in sentencing. Thus, sentencing reform, which developed from the civil rights movement and was motivated by concerns for fairness to prisoners, was primarily focused on eliminating racial bias and primarily committed to values of equal treatment. Without giving it much attention, sentencing reformers assumed that the logics of racial and gender injustice were similar, requiring similar methods of redress.

In every jurisdiction that changed its sentencing policies and attempted to establish sentencing guidelines, three propositions were taken as self-evident. First, race and gender were believed to be illegitimate considerations in sentencing. Second, other factors like education and employment were considered to be forbidden or discouraged because they would work systematically and directly to the detriment of poor defendants and, because proportionately more blacks than whites were poor, indirectly to the detriment of black defendants. Third, because most judges then (as now) were white men, it was assumed that, if given broad discretion, they would be influenced by conscious or unconscious prejudice toward members of minority groups. Thus, it was decided that sentencing should be based on the nature and seriousness of the crime and that judicial discretion should be tightly constrained.

Gender was largely absent from the debates and calculations: if race was a forbidden consideration, so self-evidently was gender. Equal treatment was (and is) a seductive criminal justice ideology; there appeared to be no legal or policy alternative. An immediate difficulty arose, however, from reviews of the statistical research literature (Blumstein et al. 1983; Nagel and Hagan 1983). After controlling for the defendant's prior record of arrests or convictions, and the type and severity of the convicted charge, women's sentences appeared to be less severe than men's. If future sentences were to be based on past average sentences for men or on an average of men's and women's sentences (no jurisdiction considered using average sentences for women), the policy choice was between "equal treatment" (i.e., using past averages and applying them both to men and women) or "special treatment" (i.e., preserving a two-track system in which it appeared that women were sentenced less severely).

Every jurisdiction we are aware of, including Minnesota, Pennsylva- 
nia, Washington, Oregon, Kansas, North Carolina, and the federal sentencing commission, opted for equal treatment. They used the seriousness of the current offense and measures of previous lawbreaking to set sentencing standards. This translated to harsher sentences for women. In Minnesota, policy makers were conscious of the trade-offs. They decided that it was preferable to endorse the symbolism of gender-neutral equal treatment than to be concerned with potential increases in sentences for women (Parent 1988). An evaluation of the first three years of implementing the guidelines suggests that gender disparities in sentencing were reduced and that women's sentences became more severe (Knapp 1984). Monitoring data from most guideline systems show the same pattern of increased sentencing severity for women (e.g., Bogan and Factor 1995, p. 13).

While race- and gender-based disparities may be reduced with "equal treatment" sentencing policies, there are negative consequences, as well. First, the decision to restrict sentencing criteria to current and past lawbreaking makes it difficult for judges to mitigate sentences to take account of offenders' personal circumstances. Since relatively few felony defendants come from middle-class backgrounds and close to half are black, an equal treatment policy disadvantages those poor, minority defendants whose lives show some social and economic success. Second, it is difficult for judges to tailor sentences to the distinctive demands of justice that are linked to racial, class, and gender differences. Race and gender relations have different histories and logics; at the same time, criminal justice policies may also suffer from viewing race and gender as being on separate tracks. By separatetrack thinking, we mean policies that address what are seen as special or unique problems of minority group members or of women. How to imagine the intersections of racial-ethnic and gender relations, while also appreciating their different logics and demands of justice, will continue to pose dilemmas for crime and justice policy.

This essay examines the sentencing literature with the following questions in mind. What does the research show? How are race and gender conceptualized in the criminal process? What are the policy implications of theory and research in this area? The essay has five parts. The first summarizes data on arrest, confinement, and sentencing trends by race and by gender over the past two decades. The second surveys the statistical literature on race and gender disparities in sentencing; the third reviews several theoretical perspectives that have been proposed for thinking about race-gender intersectionalities; and 
the fourth considers racial and gender politics in sentencing reform. The last offers recommendations for policy and future research. Before turning to these discussions at the beginning of Section I we discuss problems with terms such as "race," "crime," and "justice" and the limits of available data.

\section{Race and Gender in Official Statistics}

As anthropologists have long emphasized, "race" does not exist, that is, "there are no clearly isolatable populations of human beings that vary from one another significantly on ... physical dimensions" (Meneses 1994 , p. 139). Race refers instead to socially and historically constructed categories and identities. Like ethnicity and cultural identity, race may be best understood as a "means of group formation rather than the cause of it" (p. 141) (see also Georges-Abeyie 1989; Roediger 1991; Hall 1992; Frankenberg 1993; Ang 1995). However much anthropologists, historians, and biological scientists (among others) may stress that race, as a set of biological categories for human populations, does not exist, or that ethnic identities are actively constructed without clear origins or consistent elements, it is difficult to convince people of these ideas. Meneses (1994, p. 139) suggests that the reason is that people hold a "firm commitment to a folk theory of race . . . because of the convenience of marking ethnic groups ... with physical features and because the symbolism of common ancestry . . . is powerful to maintain ethnic group coherence." In addition to fixed notions of "race," in the United States, the "black-white" racial dualism obscures a more complex picture of racial and ethnic relations, especially the relational histories of Hispanic Americans, Native Americans, African Americans, and Asian Americans to each other (Mann 1993; Martinez 1993; Takaki 1993; Omi and Winant 1994).

There is a sharp disjuncture between a contextual and socially constructed understanding of race and ethnicity and how statistical data on crime, courts, and prisons are gathered. Statistical categorization presumes a fixed quality or "essence" to racial and ethnic differences, when such differences are more fluid. But even if one wanted to work with extant statistical categories, the data on racial and ethnic categories may be available in some sources (e.g., arrest and prison populations) but fragmentary or absent in others (e.g., victimization and national court data). This makes comparisons across data sources difficult. Another major problem is that, with some exceptions, crime and justice system data lack measures of class standing; thus, analyses 
use "race" as a surrogate for discussing class and crime, when a more satisfactory approach would be to analyze class and race together. Despite these recognized problems, we use the national data available to us and the folk theory of race on which the data are based: black and white as dichotomous race groups, and without reference to class standing.

"Male" and "female" have a more secure biological referent, and the statistical categorization of gender groups is somewhat less contentious than that for race and ethnicity (but for feminist challenges, see Gatens [1996]). Yet serious problems remain. Arrest and court data examine race and gender separately, but not together. This is a major problem because the most interesting analytical and political questions center on the intersections of race and gender, not merely the separate categories of "black," "white," "male," and "female."

Crime and justice system data are limited by the very terms in which these phenomena are counted and explained: crime is a state-created definition and phenomenon. That is not to say that harms of various types are not "real" or that people do not suffer them, but that certain harms are more easily counted and detected than others (common law crimes compared with various organizational and occupational crimes, or crimes between strangers compared with crimes between intimates) and that certain offenses become a targeted focus of policing and criminal justice activity. The historical shifts in the meaning and content of particular crime categories, themselves heterogeneous groupings of diverse harms, must always be kept in mind.

Although this essay does not address the sociological and philosophical literature on crime, punishment, and justice, we find Hudson's (1996, pp. 151-52) distinction between punishment and justice a useful one. She argues that "punishment cannot be a synonym for "justice" ": whereas the former concerns the infliction of pain, the latter concerns "the balance between individual freedom and social responsibility [and] ... the fair distribution of the rights and responsibilities of citizenship." When we use the phrase "the distinctive demands of justice," we have in mind a meaning of justice as the "right" response to the particulars of the harm and the case. We argue that race and gender relations have different histories and logics, and by that we refer to the mechanisms and practices by which racial and gender oppression are structured, enacted, reproduced, and challenged. Ultimately, more "just" decisions in individual cases (or across groups of cases) would address these broader configurations of inequality. Current sentencing policy remains rooted in notions of individual responsibility, denying 
the larger societal inequalities and histories of race and gender relations. Within these narrowly circumscribed terms, however, there remain competing demands of racial and gender justice, which scholars and policy makers have not yet addressed.

\section{A. Arrests}

Because arrests are the starting point of the criminal process, they set basic patterns on which later official decisions embroider. They also provide the first indication that patterns of lawbreaking differ for blacks compared with whites and for women compared with men, even though blacks and women both occupy subordinated social positions. Arrests do not give an optimal picture of criminal behavior, and no one is sure how good a picture they do give. Some unlawful behavior results in people being taken into custody, and some takings into custody result in arrests being officially entered in police records. Policies and conventions governing such decisions vary over time and place; arrest data are as much a measure of official behavior as of criminal behavior.

Thus, when examining gender, race, and arrest statistics over time, it is unclear whether apparent shifts in the black or female share of arrests reflect "real" changes in lawbreaking or changes in police responses to crime. Varied data sources suggest that there are "real" race and gender differences in crime involvement, especially with street forms of violent crime (blacks higher and women lower) and elite or white-collar forms of property crime (men and whites higher) (see Blumstein 1982; Daly 1989c; Harris and Meidling 1994; Tonry 1995, pp. 49-80). However, cross-national trend data on gender and arrests suggest that enhanced police record-keeping practices, coupled with credit-based currency systems, can explain increases in women's arrests for the less serious forms of property crime and fraud (Steffensmeier, Allan, and Streifel 1989; Steffensmeier 1993, 1995).

1. Gender and Arrests. The data on gender and arrests show three patterns (table 1, pts. A-C). ${ }^{5}$ First, arrest rates for women are lower than for men. For all offenses combined, men's arrest rates are over four times greater than women's. Second, men's and women's arrest

${ }^{5}$ Our tables are similar to Steffensmeier's $(1993,1995)$ method of arraying gender and arrest data in that we group the offense categories to reflect similar clusters of behavior rather than by index and nonindex offenses. Our rates of arrest differ from his, however, in that our base is the entire U.S. population whereas his is the population aged ten through sixty-four years. Also, when calculating the female (and black) shares of arrests, we use the raw numbers, not the arrest rates as Steffensmeier does. Readers will notice slight differences in our calculations as a result. 


\section{TABLE 1}

\section{Gender and Arrests}

A. Women's Arrest Rates per 100,000 , by Offense, Ranked from Most to Least Frequent, 1994

\begin{tabular}{ccl}
\hline $\begin{array}{l}\text { Rank and Number } \\
\text { of Arrests }\end{array}$ & $\begin{array}{c}\text { Rate per 100,000 } \\
\text { Female Population }\end{array}$ & \multicolumn{1}{c}{ Offense } \\
\hline $\begin{array}{c}\text { Moderate: } \\
546,304\end{array}$ & & \\
411,331 & 410 & All other offenses (except traffic) \\
Moderate-low: & 309 & Larceny-theft \\
185,111 & & Simple assault \\
184,160 & 139 & Drug abuse violations \\
153,382 & 138 & Driving under the influence \\
130,239 & 115 & Fraud \\
Low: & 98 & \\
74,696 & & Aggravated assault \\
66,271 & 56 & Public drunkenness \\
53,313 & 50 & Prostitution \\
33,424 & 40 & Burglary \\
33,305 & 25 & Vandalism \\
33,206 & 25 & Forgery and counterfeiting \\
20,559 & 25 & Motor vehicle theft \\
18,057 & 15 & Stolen property \\
13,591 & 14 & Robbery \\
Very low: & 10 & Embezzlement \\
4,783 & & Arson \\
2,460 & 4 & Homicide \\
1,839 & 2 & \\
\hline $2,372,426$ & 1 & All offenses \\
\hline
\end{tabular}

B. Men's Arrest Rates per 100,000, by Offense,

Ranked from Most to Least Frequent, 1994

\begin{tabular}{|c|c|c|}
\hline $\begin{array}{l}\text { Rank and Number } \\
\text { of Arrests }\end{array}$ & $\begin{array}{l}\text { Rate per } 100,000 \\
\text { Male Population }\end{array}$ & Offense \\
\hline \multicolumn{3}{|l|}{ Very high: } \\
\hline $2,499,796$ & 1,967 & All other offenses (except traffic) \\
\hline \multicolumn{3}{|l|}{ High: } \\
\hline 934,186 & 735 & Drug abuse violations \\
\hline 926,151 & 729 & Driving under the influence \\
\hline 824,980 & 649 & Larceny-theft \\
\hline 806,770 & 635 & Simple assault \\
\hline \multicolumn{3}{|l|}{ Moderate: } \\
\hline 505,149 & 398 & Public drunkenness \\
\hline 475,167 & 374 & Disorderly conduct \\
\hline 375,020 & 295 & Aggravated assault \\
\hline 341,177 & 268 & Liquor laws \\
\hline 286,502 & 225 & Burglary \\
\hline 226,274 & 178 & Vandalism \\
\hline \multicolumn{3}{|c|}{210} \\
\hline
\end{tabular}


B. Men's Arrest Rates per 100,000 , by Offense,

Ranked from Most to Least Frequent, 1994

\begin{tabular}{ccl}
\hline $\begin{array}{l}\text { Rank and Number } \\
\text { of Arrests }\end{array}$ & $\begin{array}{c}\text { Rate per 100,000 } \\
\text { Male Population }\end{array}$ & \multicolumn{1}{c}{ Offense } \\
\hline 200,513 & 158 & Fraud \\
196,232 & 154 & Weapons \\
$\begin{array}{c}\text { Moderate-low: } \\
145,701\end{array}$ & 115 & Motor vehicle theft \\
133,388 & 105 & Robbery \\
116,873 & 92 & Stolen property \\
Low: & & \\
74,991 & 59 & Sex offenses \\
73,000 & 57 & Offenses against family and children \\
59,797 & 47 & Forgery and counterfeiting \\
33,505 & 26 & Prostitution \\
29,460 & 23 & Rape \\
16,958 & 13 & Vagrancy \\
16,658 & 13 & Homicide \\
14,304 & 11 & Arson \\
\hline $9,504,762$ & 7,480 & All offenses \\
\hline
\end{tabular}

C. Female Share of Arrests, 1975, 1980, 1990, 1994, in Percent

\begin{tabular}{|c|c|c|c|c|}
\hline & 1975 & 1980 & 1990 & 1994 \\
\hline All offenses & 16 & 16 & 18 & 20 \\
\hline \multicolumn{5}{|l|}{ Index offenses only: } \\
\hline Violent index & 10 & 10 & 11 & 14 \\
\hline Property index & 22 & 21 & 25 & 27 \\
\hline \multicolumn{5}{|l|}{ Offenses against the person: } \\
\hline Homicide & 16 & 13 & 10 & 10 \\
\hline Aggravated assault & 13 & 12 & 13 & 17 \\
\hline Simple assault & 14 & 14 & 16 & 19 \\
\hline \multicolumn{5}{|l|}{ Major property: } \\
\hline Robbery & 7 & 7 & 8 & 9 \\
\hline Burglary & 5 & 6 & 9 & 10 \\
\hline Stolen property & 11 & 11 & 12 & 13 \\
\hline \multicolumn{5}{|l|}{ Minor property: } \\
\hline Larceny-theft & 31 & 29 & 32 & 33 \\
\hline Fraud & 34 & 41 & 44 & 39 \\
\hline Forgery & 29 & 31 & 35 & 36 \\
\hline Embezzlement & 31 & 29 & 41 & 41 \\
\hline \multicolumn{5}{|l|}{ Drinking, drugs, public order: } \\
\hline Public drunkenness & 7 & 8 & 10 & 12 \\
\hline Driving under the influence & 8 & 9 & 13 & 14 \\
\hline Drug abuse violations & 14 & 13 & 17 & 17 \\
\hline Disorderly conduct & 18 & 16 & 19 & 21 \\
\hline \multirow[t]{2}{*}{ Prostitution } & 74 & 70 & 64 & 61 \\
\hline & 21 & & & \\
\hline
\end{tabular}


TABLE 1 (Continued)

D. Offenses Showing the Largest Increase in Women's and

Men's Total Arrests, 1975 and 1994

\begin{tabular}{lrrc}
\hline & 1975 & 1994 & $\begin{array}{c}\text { Rate of Increase } \\
\text { (in Percent) }\end{array}$ \\
\hline Women: & & & \\
Simple assault & 48,745 & 185,111 & 280 \\
Aggravated assault & 26,394 & 74,696 & 183 \\
Liquor laws & 38,124 & 83,275 & 118 \\
Fraud & 50,004 & 130,239 & 130 \\
All other (except traffic) & 167,465 & 546,304 & 226 \\
Drug abuse violations & 70,060 & 184,160 & 163 \\
Men: & & & \\
Simple assault & 303,903 & 806,770 & 165 \\
Aggravated assault & 175,823 & 375,020 & 113 \\
Liquor laws & 228,933 & 341,177 & 49 \\
Fraud & 96,249 & 200,513 & 108 \\
All other (except traffic) & 870,289 & $2,499,796$ & 187 \\
Drug abuse violations & 438,129 & 934,186 & 113 \\
\hline
\end{tabular}

Sources.-For pts. A and B: Federal Bureau of Investigation (1995), table 42; U.S. Department of Commerce (1996), table 12. For pt. C: Federal Bureau of Investigation (1976), table 38; (1981), table 35; (1991), table 37; (1995), table 42. For pt. D: Federal Bureau of Investigation (1976), table 38; (1995), table 42.

NoTE. - The arrest rate is calculated from FBI data on arrests by sex and census data on population by sex (female population $=133,265,000$; male population = $127,076,000)$. The total amounts for both women and men do not equal the amounts shown in columns; some arrest categories are omitted.

rates are high for driving under the influence, larceny-theft, and a residual set of "other offenses," and they are low for homicide, embezzlement, and arson. Gender differences are evident in the middle ranges: men's arrest profile contains a higher share of arrests for major forms of violent and property crime, whereas women's contain a higher share of arrests for more minor forms of property crime. Third, while the female share of overall arrests is lower than men's, this share has increased from 16 to 20 percent from 1975 to 1994 . For both men and women, arrest rates have increased most for simple and aggravated assault, the residual "other offense" category, drug law violations, and fraud. The female share of arrests for serious violent offenses (homicide, aggravated assault, and robbery) was 12 percent in 1975 and 1990, rising to 14 percent in 1994.

2. Race and Arrests. When arrests for blacks and whites are com- 
pared, three patterns stand out (table 2, pts. A-C). First, arrest rates for blacks are higher than for whites. For all offenses combined, they are nearly four times higher. Second, blacks' and whites' arrest rates are high for drug law violations, simple assault, larceny-theft, and a residual set of "other offenses." They are relatively lower for arson, embezzlement, and homicide. There are significant differences. Disorderly conduct and aggravated assault are high-arrest rate offenses for blacks, whereas driving under the influence is for whites. Third, the overall black share of arrests has risen from 25 percent of arrests in 1974 and in 1980 to 31 percent in 1994. During the past two decades, the black share of arrests for most offenses has moved up or down by only a few percentage points. The major exception is drug law violations: whereas the black share of arrests for this offense category was 20 percent in 1975, it was 41 percent in 1990, dropping a bit to 38 percent in 1994.

3. Gender, Race, and Arrests. Scholars draw from the Federal Bureau of Investigation's Uniform Crime Reports data, National Crime Victimization Survey data, and adolescents' self-reported involvement in crime and delinquency to analyze race and gender together. This body of research shows that women are less likely than men to be involved in crime but that black women's involvement is higher than white women's (Young 1980; Lewis 1981; Mann 1984; Laub and McDermott 1985; Chilton and Datesman 1987; Hill and Crawford 1990; Simpson 1991). Several studies suggest that, in similar crime situations, black women are more likely to be arrested than white women (Visher 1983; Smith, Visher, and Davidson 1984). The race-gender hierarchy from most to least likely to be arrested for common crime (or to be perceived as an offender) is black men, white men, black women, and white women. Black-white differences for men and women in rates of arrest (or perceived race of offender for National Crime Victimization Survey data) are especially strong for violent crime, but less so for property crime.

\section{B. Confinement in Prisons and fails}

The number of sentenced prisoners in state and federal prisons in the United States has increased dramatically in the past fifteen years. In 1980 , there were about 330,000 prisoners. By the end of 1995 there were $1,078,000$, more than three times as many (Bureau of Justice Statistics 1996). Data on admissions to state prisons reveal three changes since 1980. First, court commitments are a decreasing share of prison 


\section{TABLE 2}

\section{Race and Arrests}

A. Black Arrest Rates per 100,000 , by Offense,

Ranked from Most to Least Frequent, 1994

\begin{tabular}{|c|c|c|}
\hline $\begin{array}{l}\text { Rank and Number } \\
\text { of Arrests }\end{array}$ & $\begin{array}{l}\text { Rate per } 100,000 \\
\text { Black Population }\end{array}$ & Offense \\
\hline \multicolumn{3}{|l|}{ Very high: } \\
\hline $1,092,034$ & 3,342 & All other offenses (except traffic) \\
\hline \multicolumn{3}{|l|}{ Very high-high: } \\
\hline 429,479 & 1,315 & Drug abuse violations \\
\hline 407,231 & 1,246 & Larceny-theft \\
\hline 341,941 & 1,047 & Simple assault \\
\hline \multicolumn{3}{|l|}{ High: } \\
\hline 199,094 & 609 & Disorderly conduct \\
\hline 176,062 & 539 & Aggravated assault \\
\hline \multicolumn{3}{|l|}{ Moderate: } \\
\hline 120,640 & 369 & Fraud \\
\hline 107,347 & 329 & Driving under the influence \\
\hline 97,867 & 300 & Burglary \\
\hline 96,200 & 294 & Drunkenness \\
\hline 89,232 & 273 & Robbery \\
\hline 87,531 & 268 & Weapons \\
\hline 66,544 & 204 & Motor vehicle theft \\
\hline 59,083 & 181 & Vandalism \\
\hline 57,575 & 176 & Liquor laws \\
\hline 54,601 & 167 & Stolen property \\
\hline \multicolumn{3}{|l|}{ Moderate-low: } \\
\hline 32,001 & 98 & Forgery and counterfeiting \\
\hline 30,860 & 94 & Prostitution \\
\hline 30,242 & 93 & Offenses against family and children \\
\hline \multicolumn{3}{|l|}{ Low: } \\
\hline 12,419 & 38 & Rape \\
\hline 10,420 & 32 & Homicide \\
\hline 3,853 & 12 & Arson \\
\hline 3,816 & 12 & Embezzlement \\
\hline $3,705,713$ & 11,342 & All offenses \\
\hline
\end{tabular}

B. White Arrest Rates per 100,000, by Offense,

Ranked from Most to Least Frequent, 1994

$\begin{array}{lll}\begin{array}{l}\text { Rank and Number } \\ \text { of Arrests }\end{array} & \begin{array}{l}\text { Rate per 100,000 } \\ \text { White Population }\end{array} & \text { Offense }\end{array}$

$\begin{array}{lll}\begin{array}{l}\text { High: } \\ \text { 1,891,312 } \\ \text { Moderate: }\end{array} & 874 & \text { All other offenses (except traffic) } \\ 932,802 & 431 & \text { Driving under the influence } \\ 796,212 & 368 & \text { Larceny-theft } \\ 677,025 & 313 & \text { Drug abuse violations }\end{array}$


TABLE 2 (Continued)

B. White Arrest Rates per 100,000, by Offense,

Ranked from Most to Least Frequent, 1994

\begin{tabular}{ccl}
\hline $\begin{array}{l}\text { Rank and Number } \\
\text { of Arrests }\end{array}$ & $\begin{array}{c}\text { Rate per 100,000 } \\
\text { White Population }\end{array}$ & \multicolumn{1}{c}{ Offense } \\
\hline 625,689 & 289 & Simple assault \\
460,300 & 213 & $\begin{array}{l}\text { Drunkenness } \\
390,326\end{array}$ \\
352,683 & 180 & Disorderly conduct \\
Moderate-low: & 163 & Liquor laws \\
264,466 & & \\
215,363 & 122 & Aggravated assault \\
205,362 & 99 & Burglary \\
Low: & 95 & Fraud \\
193,538 & & \\
121,834 & 89 & Vandalism \\
95,216 & 56 & Weapons \\
77,709 & 44 & Motor vehicle theft \\
62,300 & 36 & Stolen property \\
59,127 & 29 & Sex offenses \\
58,427 & 27 & Forgery and counterfeiting \\
55,055 & 27 & Offenses against family and children \\
53,819 & 25 & Robbery \\
Very low: & 25 & Prostitution \\
16,683 & & \\
12,555 & 8 & Rape \\
7,705 & 6 & Arson \\
7,600 & 4 & Homicide \\
\hline $7,894,414$ & 4 & Embezzlement \\
\hline & 3,647 & All offenses \\
\hline
\end{tabular}

C. Black Share of Arrests, 1975, 1980, 1990, 1994, in Percent

\begin{tabular}{lcccc}
\hline & 1975 & 1980 & 1990 & 1994 \\
\hline All offenses & 25 & 25 & 29 & 31 \\
Index offenses only: & & & & \\
$\quad$ Violent index & 47 & 44 & 45 & 45 \\
$\quad$ Property index & 31 & 33 & 30 & 30 \\
Offenses against the person: & & & & \\
$\quad$ Homicide & 54 & 48 & 55 & 56 \\
$\quad$ Aggravated assault & 40 & 36 & 38 & 39 \\
$\quad$ Simple assault & 34 & 32 & 34 & 35 \\
Major property: & & & & \\
$\quad$ Robbery & 59 & 58 & 61 & 61 \\
$\quad$ Burglary & 28 & 29 & 30 & 31 \\
$\quad$ Stolen property & 34 & 32 & 41 & 41 \\
Minor property: & & & & \\
$\quad$ Larceny-theft & 31 & 31 & 31 & 33 \\
$\quad$ Fraud & 29 & 30 & 33 & 37
\end{tabular}


TABLE 2 (Continued)

\begin{tabular}{|c|c|c|c|c|}
\hline \multicolumn{5}{|c|}{ C. Black Share of Arrests, $1975,1980,1990,1994$, in Percent } \\
\hline Forgery & 33 & 33 & 34 & 34 \\
\hline Embezzlement & 31 & 24 & 32 & 33 \\
\hline \multicolumn{5}{|l|}{ Drinking, drugs, public order: } \\
\hline Public drunkenness & 19 & 16 & 18 & 17 \\
\hline Driving under the influence & 13 & 11 & 9 & 10 \\
\hline Drug abuse violations & 20 & 24 & 41 & 38 \\
\hline Disorderly conduct & 30 & 30 & 32 & 33 \\
\hline Prostitution & 54 & 53 & 39 & 36 \\
\hline
\end{tabular}

D. Offenses Showing the Largest Increase in Blacks' and Whites' Total Arrests, 1975 and 1994

\begin{tabular}{lrrr}
\hline & 1975 & 1994 & $\begin{array}{c}\text { Rate of Increase } \\
\text { (in Percent) }\end{array}$ \\
\hline Blacks: & & & \\
Drugs & 96,660 & 429,479 & 344 \\
All other & 267,294 & $1,092,034$ & 309 \\
Simple assault & 113,608 & 341,941 & 201 \\
Fraud & 40,476 & 120,640 & 198 \\
Aggravated assault & 71,360 & 176,062 & 147 \\
Vandalism & 25,149 & 59,083 & 135 \\
Whites: & & & \\
Simple assault & 217,481 & 625,689 & 188 \\
All other & 696,160 & $1,891,312$ & 172 \\
Aggravated assault & 105,226 & 264,466 & 151 \\
Fraud & 99,972 & 205,362 & 105 \\
Drugs & 383,649 & 677,025 & 76 \\
Weapons & 69,843 & 121,834 & 74 \\
\hline
\end{tabular}

Sources.-For pts. A and B: Federal Bureau of Investigation (1995), table 42; U.S. Department of Commerce (1996), table 12. For pt. C: Federal Bureau of Investigation (1976), table 38; (1981), table 35; (1991), table 37; (1995), table 42. For pt. D: Federal Bureau of Investigation (1976), table 39; (1995), table 43.

Note.-The arrest rate is calculated from FBI data on arrests by race and census data on population by race (black population $=32,672,000$; white population $=$ $216,470,000)$. The total amounts for both blacks and whites do not equal the amounts shown in columns; some arrest categories are omitted.

admissions (70 percent in 1992) whereas "conditional release violators" (those who left prison as parolees or by other types of release involving community supervision) form an increasing share (from 17 percent in 1980 to 30 percent in 1992). Second, court commitments have increased dramatically for drug offenses, rising from about 2 percent to 10 percent of drug arrests (Bureau of Justice Statistics 1994a, 


\section{TABLE 3}

Rates per 100,000 of Federal and State Sentenced Prisoners, by Gender and Race, 1980-1993

\begin{tabular}{lcccccr}
\hline & & \multicolumn{2}{c}{ Men } & & \multicolumn{2}{c}{ Women } \\
\cline { 7 - 7 } \cline { 6 - 7 } Year & Total* & White & Black & & White & Black \\
\hline 1980 & 139 & 168 & 1,111 & & 6 & 45 \\
1984 & 187 & 228 & 1,459 & & 93 & 63 \\
1990 & 297 & 339 & 2,376 & & 19 & 125 \\
1993 & 359 & 398 & 2,920 & & 23 & 165 \\
$\begin{array}{l}\text { Rate of increase, } \\
\quad \text { (in percent) }\end{array}$ & & & & & & \\
$1980-1993$ & 158 & 137 & 163 & 283 & 267 \\
\hline
\end{tabular}

Source.-Adapted from Bureau of Justice Statistics (1994a), p. 9.

*Total includes prisoners of other racial-ethnic groups.

p. 8). In 1980,7 percent of new court commitments were for drug offenses; in 1992, it was 31 percent. Third, the black share of those imprisoned has increased from 44 percent in 1980 to 47 percent in 1994; for women, from 4 percent to 6 percent. While the rate of increase in incarceration has been greatest for black and white women, their increased numbers are a small portion of the overall growth in the size of the prison population, which has been shouldered disproportionately by black men.

Table 3 shows incarceration rates by race and gender for state and federal prisoners from 1980 to 1993. Black men's incarceration rate was six times that of white men's in 1980, seven times that in 1990, and eight times that in 1993. Black women's incarceration rate was seven times that of white women's in 1980 and in 1993. Gender differences within racial groups are even more pronounced. Black men's incarceration rate was eighteen times that of black women in 1993 (it was twenty-five times that of black women in 1980). White men's incarceration rate was seventeen times that of white women in 1993 (it was twenty-eight times that of white women in 1980).

For men and women in prison in 1991, the median age is thirty to thirty-one years (table 4). Nearly two-thirds are members of minority groups (black, Hispanic, Native American, and Asian), and most have not graduated from high school. Over half the women and 32 percent of the men were unemployed at the time of arrest. More imprisoned 
TABLE 4

Demographic, Offense, and Criminal History Profiles of Men and Women in State Prisons in 1991 and Jails in 1989 (in Percent)

\begin{tabular}{|c|c|c|c|c|}
\hline & \multicolumn{2}{|c|}{ In Prison } & \multicolumn{2}{|c|}{ In Jail } \\
\hline & Men & Women & Men & Women \\
\hline Median age (in years) & 31 & 30 & 28 & 28 \\
\hline \multicolumn{5}{|l|}{ Race/ethnicity: } \\
\hline White, non-Hispanic & 35 & 36 & 39 & 38 \\
\hline Black, non-Hispanic & 46 & 46 & 42 & 43 \\
\hline Hispanic & 17 & 14 & 17 & 16 \\
\hline Other & 2 & 4 & 2 & 3 \\
\hline \multicolumn{5}{|l|}{ Education: } \\
\hline Eighth grade or less & 20 & 16 & 16 & 12 \\
\hline Some high school & 46 & 46 & 38 & 38 \\
\hline High school graduate or more & 34 & 28 & 46 & 50 \\
\hline \multicolumn{5}{|l|}{ Prearrest employment: } \\
\hline Employed & 69 & 47 & 68 & 38 \\
\hline Unemployed, looking & 16 & 19 & 20 & 28 \\
\hline Unemployed, not looking & 15 & 34 & 12 & 34 \\
\hline \multicolumn{5}{|l|}{ Offense: } \\
\hline Violent & 47 & 32 & 24 & 13 \\
\hline Property & 25 & 29 & 30 & 32 \\
\hline \multicolumn{5}{|l|}{ Drugs: } \\
\hline Possession & 7 & 12 & 9 & 15 \\
\hline Trafficking & 13 & 20 & 12 & 17 \\
\hline Public order & 7 & 6 & 23 & 19 \\
\hline Other & 1 & 1 & 2 & 4 \\
\hline \multicolumn{5}{|l|}{ Criminal history: } \\
\hline \multicolumn{5}{|l|}{ Not sentenced to probation or incar- } \\
\hline \multicolumn{5}{|l|}{ Previously sentenced for violent } \\
\hline offense & 50 & 26 & 31 & 16 \\
\hline \multicolumn{5}{|l|}{ Previously sentenced for nonviolent } \\
\hline offense & 31 & 46 & 47 & 52 \\
\hline \multicolumn{5}{|l|}{ Level of conviction: } \\
\hline No prior record & 20 & 29 & 22 & 33 \\
\hline One conviction & 19 & 22 & 21 & 20 \\
\hline Two or more convictions & 61 & 49 & 57 & 47 \\
\hline
\end{tabular}

Sources.-Prison data for 1991 are adapted from Bureau of Justice Statistics (1994b), pp. 2-4. Jail data for 1989 are adapted from Bureau of Justice Statistics (1992), pp. 3-6.

NoTE.-The sample sizes on which these percents are based may vary depending on whether there is complete information. For prison data, the $N$ of women and men is about 38,700 and 670,000 , respectively. For jail, the $N$ is for all inmates, convicted and not convicted. In 1989 , that was about 36,500 women and 344,500 men. 
men (close to half) were in prison for violent offenses than were women (one-third). More imprisoned women (one-third) were in for drug offenses than were men (20 percent), although just five years earlier, drug offenses accounted for 11 and 8 percent, respectively, of the offenses for which women and men were incarcerated. More incarcerated men ( 50 percent) than women ( 26 percent) had been previously convicted of a violent offense, and more men (61 percent) than women (49 percent) had two or more previous convictions.

In addition to those in prison, there were 507,000 people in U.S. jails in 1995 (Bureau of Justice Statistics 1996). Forty-five percent were convicted and serving sentences; the rest were awaiting trial. The number of adults in local jails more than doubled from 1983 to 1995 , and the increases were greater for women than men. A 1989 survey of inmates in local jails reveals a profile with some similarities and differences from that of prison inmates (table 4). Women were then 9 percent of jail inmates; most men and women ( 62 percent) were members of minority groups (black, Hispanic, and Native American/Asian), and half of women and 46 percent of men had completed high school or more. Compared to the prison population, fewer men and women were in jail for violent offenses; they were more likely to be jailed for public order offenses. Like women prisoners, jailed women were less likely than their male counterparts to have been sentenced before and less likely to have been sentenced for a violent crime.

\section{Criminal Courts}

Compared with data gathered on arrests, on jail and prison inmates, and on federal criminal courts, a national reporting system for state criminal courts has taken longer to develop. Four sources are available, although two have ended recently. These are the Prosecution of Felony Arrests (PFA), Offender-Based Transaction Statistics (OBTS), the National Judicial Reporting Program (NJRP), and the National Pretrial Reporting Program (NPRP).

The PFA is a county-level program; the OBTS, state-level. Both began in the late 1970s and ended in the early 1990s. The PFA data set includes a varied number of urban felony courts (ranging from fourteen to thirty-seven), which volunteered to report information on cases from arrest to disposition (Boland, Brady, et al. 1983; Boland, Conly, et al. 1990). The PFA statistics give the estimated percent of felony arrests dismissed and prosecuted, the percent of cases going to trial, 
and the kinds of sentences imposed. Outcomes are not disaggregated by race or gender.

State participation in the OBTS was voluntary; thus, the completeness of data varies by state. ${ }^{6}$ The OBTS contains information on outcomes from arrest to sentencing. While the gender and race composition of those prosecuted is reported, sentencing outcomes are not disaggregated by race or gender.

After several pilot efforts (see, e.g., Bureau of Justice Statistics 1987), the NJRP began in 1986 with a sample of state courts in 100 counties; the sample expanded to state courts in 300 counties in 1988. The NJRP gathers information on sentences for convicted defendants only. To supplement the NJRP, the NPRP, which began in 1988, gathers data on the pretrial status of defendants. The NPRP uses a sample of the seventy-five largest urban counties, whereas the NJRP uses both a national sample and courts serving the seventy-five largest urban counties. (We refer to the latter two NJRP samples as the "national" and "urban-county" samples, respectively.) The data from the NJRP provide the only national source of information on felony court sentences for race and gender groups. ${ }^{\text {? }}$

We have described these sources of court data in some detail because, depending on which source is consulted, the race and gender profile varies. Table 5 shows the black and female shares of cases in 1990, drawing from three data sources: the OBTS (table 5, pt. A), NJRP urban county sample (table 5, pt. B), and NJRP national sample (table 5, pt. C). In all three samples, 14-15 percent of the defendants were women. However, the black share of defendants is greater in the NJRP urban-county sample (table 5 , pt. B; 55 percent) than in the OBTS national sample (table 5, pt. A; 41 percent) or NJRP national

\footnotetext{
${ }^{6}$ An early OBTS report described sentencing practices for thirteen states during 1979-82 (Bureau of Justice Statistics 1984). Disposition data from five states were reported for 1983-86 (Bureau of Justice Statistics 1989b); fourteen for 1988 (Bureau of Justice Statistics 1991); and eleven for 1990 (Bureau of Justice Statistics 1994c). A bureau senior statistician says that the OBTS series data generally reflect justice system practices in California because of its population in comparison to other OBTS states (Langan 1995).

${ }^{7}$ Bureau of Justice Statistics researchers suggest that comparisons of 1986 and 1990 using the national data should be made with care because the 1986 sample comes from only 100 counties. They recommend comparisons using the urban county samples (Bureau of Justice Statistics 19936, p. 7). We prefer the national sample for two reasons: it has data for 1986, and it disaggregates sentences by race and gender. One problem is that the 1986 data provide less detailed offense categories than those in later years. This can be circumvented by selecting offense categories common to 1986 and subsequent years.
} 


\section{TABLE 5}

Black and Female Percentages of Defendants Prosecuted in Felony Courts in 1990 as Estimated from Three National Sources of Data

A. Offender-Based Transaction Statistics Data for 1990 from 11 States

\begin{tabular}{lccccc}
\hline & $\begin{array}{c}\text { Black } \\
\text { Female } \\
\text { Share }\end{array}$ & $\begin{array}{c}\text { White } \\
\text { Female } \\
\text { Share }\end{array}$ & $\begin{array}{c}\text { Black } \\
\text { Male } \\
\text { Share }\end{array}$ & $\begin{array}{c}\text { White } \\
\text { Male } \\
\text { Share }\end{array}$ & $\begin{array}{c}\text { Other } \\
\text { Share }\end{array}$ \\
\hline 518,929 & 6 & 8 & 35 & 50 & 1 \\
\hline
\end{tabular}

B. National Judicial Reporting Program Data for 1990, Sample of 75

Urban Counties

\begin{tabular}{lccccc}
\hline & $\begin{array}{c}\text { Black } \\
\text { Female } \\
\text { Share }\end{array}$ & $\begin{array}{c}\text { White } \\
\text { Female } \\
\text { Share }\end{array}$ & $\begin{array}{c}\text { Black } \\
\text { Male } \\
\text { Share }\end{array}$ & $\begin{array}{c}\text { White } \\
\text { Male } \\
\text { Share }\end{array}$ & $\begin{array}{c}\text { Other } \\
\text { Share }\end{array}$ \\
\hline 50,444 & 8 & 7 & 47 & 37 & 2 \\
\hline
\end{tabular}

C. National Judicial Reporting Program Data for 1990, National Sample of 300 Counties

\begin{tabular}{lccccc}
\hline All Cases (Estimated) & $\begin{array}{c}\text { Female } \\
\text { Share }\end{array}$ & $\begin{array}{c}\text { Male } \\
\text { Share }\end{array}$ & $\begin{array}{c}\text { Black } \\
\text { Share }\end{array}$ & $\begin{array}{c}\text { White } \\
\text { Share }\end{array}$ & $\begin{array}{c}\text { Other } \\
\text { Share }\end{array}$ \\
\hline 713,000 & 14 & 86 & 47 & 52 & 1 \\
\hline
\end{tabular}

Sources.-In pt. A, Offender-Based Transaction Statistics data are from Bureau of Justice Statistics (1994c), p. 3. In pt. B, National Judicial Reporting Program data are from Bureau of Justice Statistics (1993c), p. 3. In pt. C, National Judicial Reporting Program data are from Bureau of Justice Statistics (1993a), p. 16.

Note._"Other Share" = Native American and Asian men and women. The 11 states in pt. A are Alabama, Alaska, California, Idaho, Minnesota, Missouri, Nebraska, New Jersey, New York, Vermont, and Virginia.

sample (table 5, pt. C; 47 percent). It is not surprising that the urbancounty sample has a higher percent of blacks because of the demographics of urban populations. What is important is that the race and gender composition of defendants in state felony courts is characterized accurately.

In light of the differences in how court data have been gathered, an accurate analysis of sentencing trends cannot be stitched together with OBTS data from the early 1980s and NJRP data from the mid-1980s onward. We therefore focus on the 1986 and 1990 NJRP national sample data (see tables 6-8). From 1986 to 1990, the female share of defendants remained the same (13-14 percent). The black share in- 


\section{TABLE 6}

The Female and Black Shares of Those Convicted in Felony Courts, 1986-90, Using the National Judicial Reporting Program National Sample

\begin{tabular}{lccccc}
\hline & \multicolumn{2}{c}{ Female Share } & & \multicolumn{2}{c}{ Black Share } \\
\cline { 2 - 3 } \cline { 6 - 6 } & 1986 & 1990 & & 1986 & 1990 \\
\hline All felonies (in percent) & 13 & 14 & & 40 & 47 \\
Homicide & 9 & 10 & & 46 & 56 \\
Rape & 1 & 1 & & 37 & 33 \\
Robbery & 6 & 6 & & 53 & 63 \\
Aggravated assault & 9 & 9 & & 44 & 44 \\
Burglary & 4 & 5 & & 38 & 42 \\
Larceny & 20 & 18 & & 38 & 42 \\
Drug sales ("trafficking") & 14 & 15 & & 48 & 57 \\
Other felonies & 17 & 10 & & 37 & 33 \\
\hline
\end{tabular}

Sources.-For 1986, Bureau of Justice Statistics (1990), p. 3; for 1990, Bureau of Justice Statistics (1993a), p. 16.

NoTE.-The 1986 and 1990 data are not strictly comparable in that more detailed offense categories are available in 1990. Thus, the "other felonies" share drops in 1990. In 1986, the larceny category included both larceny and fraud, but in 1990 larceny and fraud were separated.

creased from 40 to 47 percent (table 6), with the largest increases being for homicide (46 to 56 percent), robbery (53 to 63 percent), and drug sales (48 to 57 percent). (The Bureau of Justice Statistics uses the term "drug trafficking," but we use "drug sales" or "selling drugs.") Within race and gender groups, the drug sales share of court convictions increased from 13 to 20 percent of men's convictions, 15 to 22 percent of women's, 10 to 17 percent of whites', and 14 to 25 percent of blacks' (see table 7).

Turning to the sentences received (table 8, pts. A and B), several caveats are in order. First, although the severity of the offense and the defendant's prior record are typically the strongest factors, sentencing is based on a complex mix of case and biographical elements. Second, the averages reported for length of sentence combine defendants who pleaded guilty and those who were found guilty at trial. Defendants convicted at trial are likely to receive more severe sentences than those pleading guilty; previous research suggests that gender and race groups may have different mixes of trial and guilty plea sentences. ${ }^{8}$

${ }^{8}$ Zatz (1987, pp. 79-80) finds that black offenders were less likely to resolve their cases through plea bargaining than whites. Daly $(1994 a$, p. 19) estimates a higher pleabargaining rate for women ( 97 percent) than men ( 92 percent). 


\section{TABLE 7}

The Distribution of Convicted Offenses, by Gender and Race, 1986-90, Using the National Judicial Reporting Program National Sample

\begin{tabular}{|c|c|c|c|c|c|c|c|c|}
\hline & \multicolumn{2}{|c|}{ Men } & \multicolumn{2}{|c|}{ Women } & \multicolumn{2}{|c|}{ Black } & \multicolumn{2}{|c|}{ White } \\
\hline & 1986 & 1990 & 1986 & 1990 & 1986 & 1990 & 1986 & 1990 \\
\hline $\begin{array}{l}\text { Homicide, rape, robbery, } \\
\text { aggravated assault }\end{array}$ & 20 & 17 & 9 & 8 & 22 & 17 & 17 & 15 \\
\hline $\begin{array}{l}\text { Burglary, larceny, motor } \\
\text { vehicle theft }\end{array}$ & 35 & 28 & 30 & 24 & 34 & 25 & 37 & 30 \\
\hline Drug sale & 13 & 20 & 15 & 22 & 14 & 25 & 10 & 17 \\
\hline Other felonies & 32 & 35 & 46 & 46 & 30 & 33 & 36 & 38 \\
\hline
\end{tabular}

Sources.-For 1986, Bureau of Justice Statistics (1990), p. 3; for 1990, Bureau of Justice Statistics (1993a), p. 17.

Note.-All percents sum to 100 . Only those offense categories that can be compared for 1986 and 1990 are shown, leaving a large "other felonies" category. The estimated number of convictions in 1986 was 582,764 ; in $1990,829,344$.

From 1986 to 1990 , the percent of defendants receiving a prison or jail sentence rose a little from 67 to 71 percent, although the average (mean) sentence length was largely unchanged (fifty-eight to fifty-two months). In 1986, there was a 20 percentage point "gender gap" in incarceration: 70 percent of men were sentenced to prison or jail compared with 50 percent of women. That gap decreased to 17 percentage points in 1990. For men, the likelihood of imprisonment rose most sharply for drug sales (65 to 79 percent) with only slight increases for most other offenses. For women, increases were also strongest for drug sales (from 53 to 69 percent), although also sizable for aggravated assault and robbery.

Compared with the incarceration gender gap, that for race was smaller: in 1986 and 1990, the incarceration rate for blacks was 2-3 percentage points higher than for whites. For blacks, increases in incarceration were marked for drug sales (up from 67 to 78 percent) and aggravated assault (66 to 75 percent). For whites, incarceration sentences for drug sales rose from 56 to 77 percent. The "race gap" in incarceration for drugs thus declined from an 11-percentage-point difference in 1986 to near parity in 1990.

All groups in 1990 were more likely to receive an incarceration sentence than in 1986 , but as table 8 , part $\mathrm{B}$, shows, the mean sentence length dropped substantially for whites (sixty-two to forty-five 


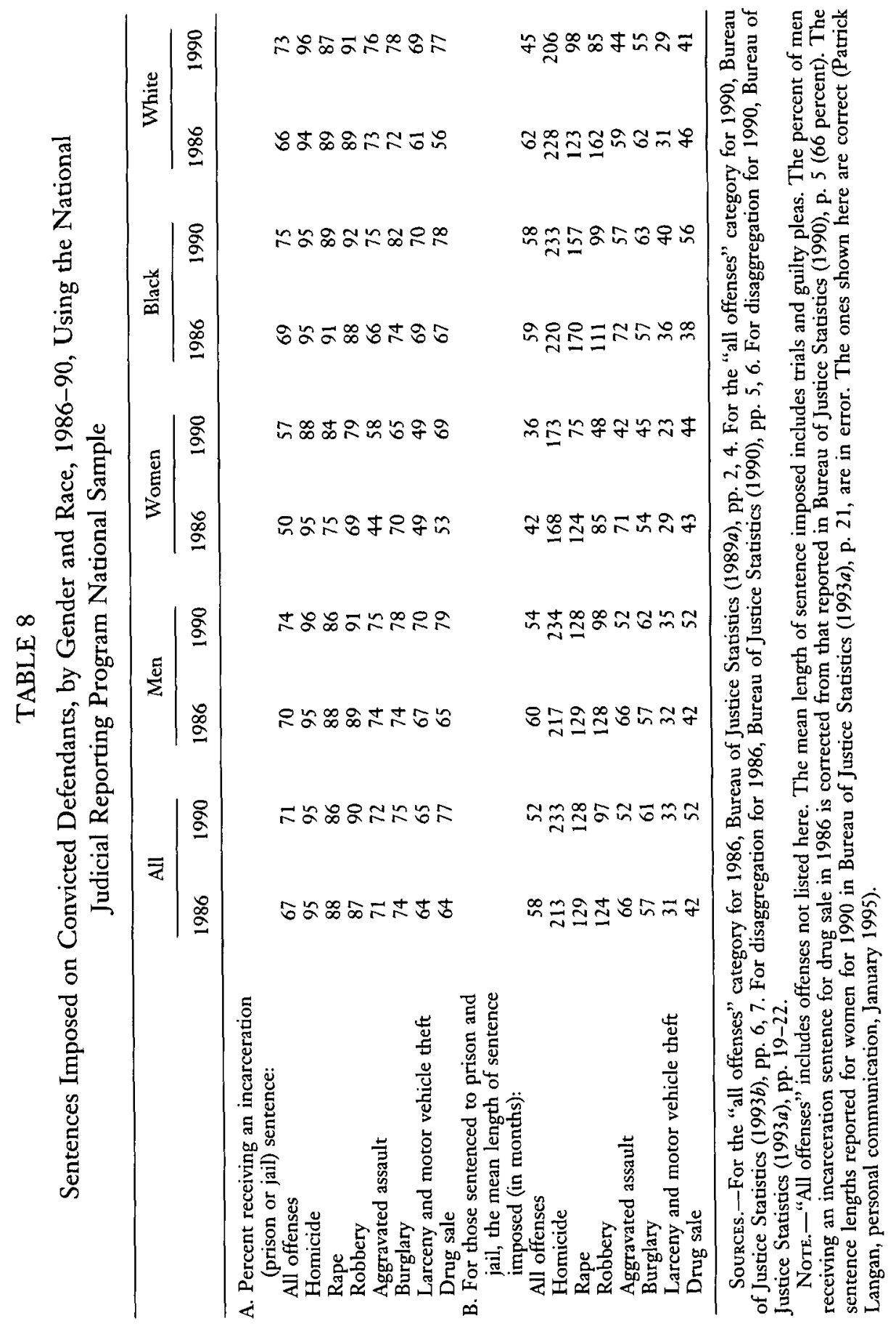


months), but not for blacks (down one month). Average sentence lengths for men and women declined by six months between 1986 and 1990. The gender gap in length of sentence in both years was eighteen months with the largest gaps for homicide and robbery. As Part B of table 8 also shows, the racial gap in length of sentence, though negligible in 1986, widened in 1990 . The largest black-white gaps were for those sentenced for rape and aggravated assault.

Because there have been significant shifts in sentencing for drug selling, we examine them for race and gender groups (table 9). From 1986 to 1992 , the percentage of drug sale cases receiving an incarceration sentence increased from 64 to 75 percent, the average sentence length increasing eight months. While the race gap in proportions receiving an incarceration sentence closed for both men and women, the race gap in sentence length reversed by 1992: it was twenty-six and twelve months longer, respectively, for black men and black women compared with their white counterparts. The gender gap for blacks and whites receiving incarceration sentences is still wide (at 14-15 percentage points), as is the gender gap in length of sentence for black defendants.

The arrest, court, and incarceration data show that for all race and gender groups, drug-related offenses have become an increasing share of arrests and felony court cases, and they have become increasingly subject to sentences of incarceration. In a very short period of time, jail and prison populations have ballooned with inmates serving time for drug-related offenses. What, then, is happening in felony courts? We turn to that research literature to see if it suggests patterns of racial and gender bias.

\section{Research on Race and Gender in Criminal Courts}

Statistical sentencing studies show that the strongest and most consistent predictors of outcomes are the severity of the offense charged and the defendant's criminal history. By comparison, defendant attributes such as race, gender, or age do not exert as strong or as consistent effects. While statistical studies can provide important information on the court process, they do not give the whole picture. Such studies show whether average sentences are more or less severe for some groups, after controlling for levels of offense severity, criminal history, and other variables, than for other groups. However, a finding of no group differences (no "race" or "sex effects") does not mean that race and gender do not powerfully influence the criminal process and the experiences of victims, offenders, attorneys, and judges. 


\section{TABLE 9}

Sentencing for Drug Sale, by Gender and Race, 1986-92, Using the National Judicial Reporting Program National Sample

A. Percent Receiving Incarceration Sentences and Length of Sentence

\begin{tabular}{|c|c|c|c|c|c|c|c|c|}
\hline For All Groups & 1986 & 1992 & & & & & & \\
\hline \multirow{4}{*}{$\begin{array}{l}\text { Percent of drug sale cases } \\
\text { receiving incarceration } \\
\text { Length of incarceration (in } \\
\text { months) }\end{array}$} & 64 & 75 & & & & & & \\
\hline & 42 & 50 & & & & & & \\
\hline & \multicolumn{2}{|c|}{$\begin{array}{l}\text { Black } \\
\text { Men }\end{array}$} & \multicolumn{2}{|c|}{$\begin{array}{c}\text { Black } \\
\text { Women }\end{array}$} & \multicolumn{2}{|c|}{$\begin{array}{l}\text { White } \\
\text { Men }\end{array}$} & \multicolumn{2}{|c|}{$\begin{array}{l}\text { White } \\
\text { Women }\end{array}$} \\
\hline & 1986 & 1992 & 1986 & 1992 & 1986 & 1992 & 1986 & 1992 \\
\hline \multirow{2}{*}{$\begin{array}{l}\text { Percent of drug sale cases } \\
\text { receiving incarceration } \\
\text { Length of incarceration } \\
\text { sentence (in months; } \\
\text { prison and jail) }\end{array}$} & 69 & 80 & 56 & 66 & 56 & 82 & 55 & 67 \\
\hline & 39 & 61 & 27 & 43 & 42 & 35 & 61 & 31 \\
\hline
\end{tabular}

B. Gender and Race Gaps in Incarceration Sentences Imposed and

Length of Sentences*

19861992

Gender gap, incarceration

sentence imposed:

$\begin{array}{lrr}\text { Blacks } & 13 & 14 \\ \text { Whites } & 1 & 15\end{array}$

Gender gap, length of sentence imposed:

Blacks

Whites

Race gap, incarceration sentence imposed:

$\begin{array}{lrr}\text { Men } & 13 & 2 \dagger \\ \text { Women } & 1 & 1 \dagger\end{array}$

Race gap, length of sentence imposed:

\begin{tabular}{lrr} 
Men & $3 \dagger$ & 26 \\
Women & $34 \dagger$ & 12 \\
\hline
\end{tabular}

Source.-Data were provided by Patrick Langan (Bureau of Justice Statistics).

* Unless otherwise indicated, the size of the gap shows the more severe sanction for men than women, and for blacks than whites.

t More severe for women than men, or for whites than blacks. 
The following review of the court literature focuses on court outcomes, not on the processes that led to those decisions. Specifically, we are not reviewing the body of observational and interview studies that explore "the [ethnographic] jungle" of legal decision making (Hawkins 1986 , p. 1242). We are also passing over research on court organizational and political contexts (e.g., Eisenstein and Jacob 1977; Blumberg 1979; Nardulli, Eisenstein, and Flemming 1988) and sociohistorical analyses of the relationship between punishment and social structure (see Melossi and Pavarini 1981; Garland 1990, 1991; Melossi 1990; Bridges and Beretta 1994; Howe 1994).

\section{A. Race and the Criminal Courts}

Those new to the criminal court literature find it hard to believe that statistical sentencing studies normally do not find "race effects" favoring whites (for reviews, see Kleck [1981]; Hagan and Bumiller [1983]; Wilbanks [1987]). How could it be that black men and women are 50 percent of those inside prison but only 12 percent of those outside without something questionable taking place in the criminal courts? Racial disparities have been documented for capital punishment in the South before the Furman v. Georgia decision in 1972 (Kleck 1981). With the reintroduction of the death penalty in the late 1970s, legal claims have centered on race-of-victim discrimination and the victimoffender relationship, not the defendant's race alone (see Baldus, Woodworth, and Pulaski 1990).

Kleck's (1981) review of studies up through the 1970s found that, of twenty-three that controlled in some way for the defendant's prior record, 56 percent found no "race effects" favoring whites. "Mixed effects," defined as one-third to one-half of the study outcomes finding race effects favoring whites, were apparent in 35 percent of studies. The remaining two of the twenty-three studies (or 9 percent) found race effects favoring whites (table 10). More recent appraisals of the literature have produced contention about the quality and interpretation of evidence (see, e.g., Blumstein et al. 1983, chap. 2; Kempf and Austin 1986; Wilbanks 1987; MacLean and Milovanovic 1990; Myers 1993; Reiner 1993; Smith 1994). Spohn (1994, p. 249) depicts researchers as falling into two camps: those arguing that racial disparity has declined and its importance is negligible compared to other case factors, and those arguing that disparity has not declined but is more difficult to detect.

Zatz (1987), a member of the latter camp, identifies four research 
TABLE 10

Findings of "Race Effects" and "Sex Effects" in Sentencing, in Percent (Excluding Studies of the Death Penalty)

\begin{tabular}{|c|c|c|c|c|}
\hline \multirow[b]{2}{*}{$\begin{array}{l}\text { Do Effects Favor } \\
\text { Whites or Women? }\end{array}$} & \multicolumn{2}{|c|}{$\begin{array}{l}\text { Race and Sentencing } \\
\text { (Kleck 1981) }\end{array}$} & \multicolumn{2}{|c|}{$\begin{array}{l}\text { Gender and Sentencing } \\
\text { (Daly and Bordt 1995) }\end{array}$} \\
\hline & $\begin{array}{c}\text { All } \\
\text { Studies } \\
(N=40)\end{array}$ & $\begin{array}{l}\text { Control for } \\
\text { Prior Record } \\
\quad(N=23)\end{array}$ & $\begin{array}{c}\text { All } \\
\text { Cases } \\
(N=50)\end{array}$ & $\begin{array}{c}\text { Control for } \\
\text { Prior Record } \\
(N=38)\end{array}$ \\
\hline Yes & 20 & 9 & 52 & 45 \\
\hline Mixed & 30 & 35 & 24 & 29 \\
\hline No & 50 & 56 & 24 & 26 \\
\hline
\end{tabular}

* "Mixed" refers to cases where one-third to one-half of the outcomes showed effects favoring whites (Kleck) or women (Daly and Bordt).

waves on race and sentencing: studies conducted up to the mid-1960s (wave 1), those in the late 1960s and 1970s (wave 2), studies in the 1970s and 1980s (wave 3), and those in the 1980s (wave 4). Wave 1 is characterized by findings of "overt discrimination against minority defendants" (Zatz 1987, p. 70). Reanalysis of these studies during wave 2 showed that, except for the imposition of the death penalty in the South, initial findings of disparity resulted from unsophisticated statistical analyses that, among other problems, lacked controls for criminal history. Wave 3 research used data from courts in the late 1960s and 1970 s, and with more sophisticated analyses found evidence of "both overt and more subtle forms of bias against minority defendants ... in some social contexts" (Zatz 1987, p. 70). In wave 4, studies did not find overt forms of bias, but subtle forms were apparent.

One of Zatz's major points-that court processing is "systematically biased due to institutionalized discrimination" (p. 81) so that the effect of race may be "indirect" or "subtle" (rather than overt) through routine court practices-anticipates a mode of analysis we consider later. Another of Zatz's points - that studies of court process may themselves be stacked against a finding of racial disparity—can be summarized here: statistical analyses may do a poor job of modeling adjudication processes and detecting various forms of disparity because they focus on discrete outcomes rather than on cumulative and structural effects of disadvantage. 


\section{B. Gender and the Criminal Courts}

Compared to race effects, sex effects are more often found in statistical sentencing studies. Reviews of the literature up to the early $1980 \mathrm{~s}$ (Parisi 1982; Nagel and Hagan 1983) found that gender differences more often arose in the pretrial release and sentencing decisions, but not in other court contexts.

A more recent appraisal of statistical sentencing by Daly and Bordt (1995) analyzed fifty unique data sets from studies published through mid-1990. They found that, of thirty-eight cases that controlled in some way for prior record, 26 percent found no sex effects, 29 percent found mixed effects, and 45 percent found effects favoring women (table 10). Statistical procedures mattered: multivariate analyses that controlled for a variety of variables, especially prior record, attenuated findings of sex effects. But even with such controls, sex effects were common.

Because the quality of the studies varied, a quality score was assigned and used to weight the cases. An analysis of the weighted sample showed that sex effects were more likely when the court analyzed was a felony court, when the jurisdiction was urban, and when a single jurisdiction was studied. Sex effects were more likely for the "in-out" (incarceration or not) decision than for sentence length. The magnitude of the gap for the in-out decision was explored in the higherquality studies: after statistical controls were introduced, the gap ranged from 8 to 25 percentage points. As to temporal effects, there appeared to be no relationship between the time period of data collection and findings of sex effects. Sex effects were as evident in more recent court disposition data sets (1976 to 1985) as in those prior to 1976. (Note that subsequent studies of jurisdictions with sentencing guidelines are few in number and that they show mixed findings: sex effects in imprisonment were evident in Pennsylvania and the federal system [Steffensmeier, Kramer, and Streifel 1993; Nagel and Johnson 1994] but not in Minnesota [Miethe and Moore 1985].)

Although the race and sentencing literature rarely grapples with gender (beyond introducing sex as a control variable), the gender and sentencing literature has been more attentive to race. The very first multivariate study of gender and race in sentencing was published only a decade ago (Gruhl, Welch, and Spohn 1984). That and subsequent quantitative studies generally find gender differences within race groups but not racial or ethnic differences within gender groups (see 
the review in Daly [1989b] and studies by Kruttschnitt [1980-81, 1982a, 1982b]; Mann [1984]; Spohn, Welch, and Gruhl [1985]; and Bickle and Peterson [1991]). From the handful of studies available, it appears that the gender gap may be widest or more often statistically significant for black defendants.

\section{Is the Statistical Sentencing Literature Misleading?}

The race and sentencing literature suggests that race has little effect on sentencing outcomes whereas the gender and sentencing literature suggests that gender bias is present but apparently working to women's advantage. Is there something wrong with these studies?

Sample selection bias is a major statistical concern; earlier screening processes in the handling of black and white cases may attenuate findings of race effects at later stages of court processing (Klepper, Nagin, and Tierney 1983). If, for example, prosecutors screened out more of the less serious white than black robbery cases at an earlier stage, the white robbery cases remaining would be, on average, more serious than the black robbery cases. A finding of "no race effects" at sentencing in this jurisdiction might be interpreted as indicating that black and white cases were treated the same, yet it does not reflect the cumulative advantage accorded whites (i.e., a higher rate of case dismissal or charge reduction).

Other related concerns are how race operates indirectly in the sentencing process (e.g., via the bail decision or type of attorney representing the defendant), how race interacts with case factors (e.g., the type of offense charged and prior record; see Zatz [1984, 1985]), how race affects sentencing for certain types of defendants or victimoffender relations, and how race differences may depend on characteristics of courts and communities (for reviews, see Reiner [1993]; Myers [1994]; and Spohn [1994]).

Statistical controls themselves may also render important racelinked sentencing elements invisible. One example is the policy decision embodied in the federal sentencing guidelines (and in some states) to impose more severe penalties on those convicted of crack compared with powdered cocaine. Because crack is more often sold by blacks, and powder by whites, the harshest penalties were largely experienced by blacks (see McDonald and Carlson [1993] and Tonry [1995, pp. 18890] for more discussion). Thus, depending on how a study is conducted, a multivariate analysis may not pick up the embeddedness of race or ethnicity in offense and statutory severity categories. 
For gender, the statistical problems are the same, but the genderembeddedness in offense variables may be even more pronounced. Specifically, the sources of variation in the character and content of men's and women's offenses and their criminal histories may be especially poorly measured. For example, suppose that male crack dealers typically dealt in larger quantities than female dealers. This might occur if men typically held higher positions in distribution networks or if more women sold small quantities to support a habit. Even a statistical analysis that controlled for many variables, including the statutory code of the conviction offense, might show that men were sentenced more harshly than women. Unless data were also available on drug quantities and on individuals' drug trafficking roles, the analysis might well (but wrongly) conclude that women were sentenced more leniently than men for these drug charges.

From Uniform Crime Report arrest data and NJRP felony court data, we know that the female share of arrests or court cases for serious interpersonal violence is low. It has been asserted, more generally, that across the spectrum of lawbreaking, women engage in less serious forms of crime and play less culpable roles than men (see, e.g., Steffensmeier 1980). Perhaps because the claim that women's lawbreaking is less serious than men's seems so self-evident, there have been few studies that have documented gender variation in crime contexts and content. They include Daly and Wilson (1987), Jurik and Gregware (1991), and Polk and Ranson (1991) on homicide, and Daly (1989c) for selected white-collar offenses.

Recent research suggests that, with better information on the nature of the offense and the defendant's prior criminal history, statistical sex effects are eroded. For example, Steffensmeier, Kramer, and Streifel (1993, p. 437) found that by introducing more precise control variables, the magnitude of sex effects in the decision to incarcerate was reduced from about 20 to 9 percentage points. Daly's (1994a) multivariate analysis of felony court sentences in New Haven, Connecticut, found a gender gap of 17 percentage points in the decision to incarcerate, but in a subsequent analysis of a smaller, deep sample of forty pairs of men and women, who were convicted of similar statutory offenses, there were negligible (though not entirely absent) gender disparities.

From Daly and Bordt's (1995) review, we learned that sex effects were more evident in felony courts than in courts prosecuting less serious offenses or a mix of felonies and misdemeanors. This implies that sources of variation in men's and women's offenses are poorly mea- 
sured for the more serious types of crimes. That inference was borne out in the New Haven felony court studied by Daly (1994a): while 48 percent of the forty pairs in the deep sample committed crimes of comparable seriousness, 40 percent of men's offenses were more serious than the women's, and 12 percent of the women's were more serious than the men's. ${ }^{9}$ In courts that dispose of the less serious types of offenses (e.g., Feeley 1979; Eaton 1986), there appears to be less statistical evidence of leniency toward women. One reason may be the kinds of offenses handled and how variation in seriousness is "controlled for" in a statistical sense.

There is, of course, more to the story of gender and sentencing than the need to improve statistical procedures. Like race and sentencing, but in a different way, the added question is how gender-linked criteria are embedded in decisions and whether such criteria are warranted or not (see also Raeder 1993; Nagel and Johnson 1994; Daly 1995; Federal Sentencing Reporter 1995). One example is a defendant's ties to and responsibilities for others, which may be used to mitigate sentences for familied defendants (those caring for or supporting others) and especially familied women (Eaton 1986; Daly 1987a, 1987b, 1989a, 1989b). Federal judges' concerns for not incarcerating "good family men" were apparent in preguidelines interviews with judges (Wheeler, Mann, and Sarat 1988). The logic in both instances is consequentialist and materialist: by separating mothers (or fathers) from families, children (or other dependents) lose sources of care and economic support. Women, more often than men, are involved in day-to-day care for others, and, depending on the offense and prior criminal history, they may benefit from this decision criterion.

A second gender-linked criterion is women's greater reform potential. Our review of jail and prison profiles showed that women do not return to court on new offenses as often as men do. We cannot be sure, of course, what part of men's more enhanced criminal histories and higher rates of recidivism is explained by state actors' behavior (e.g., the police or parole officials), by that of male lawbreakers, or by a combination of the two. We are somewhat more sure that court officials assume that women are more easily deterred than men and that women

\footnotetext{
${ }^{9}$ These summary percents can give the misleading impression that judgments of seriousness can be made easily across diverse harms. They cannot. Four chapters in Daly (1994a) discuss how to quantify and compare criminal acts for the deep sample of forty matched pairs. Gender differences in seriousness were most striking for the robbery and interpersonal violence cases and less so for the larceny and drug offense cases.
} 
will make greater efforts to reform themselves (Daly 1987a, 1989a, 1994a).

The statistical literature can therefore mislead in several ways: it can suggest that race differences are absent when they are present and that gender differences are strongly present when they are absent. Raceand gender-linked elements in criminal law, coupled with utilitarian and consequentialist decision-making, add both statistical and conceptual complications. Race and gender may be embedded in criminal law in ways that they should not be, and race and gender may be embedded in decision-making processes in ways that may be warranted and unwarranted.

\section{Conceptualizing Race and Gender in Court Practice}

Theoretical discussions of race and sentencing have drawn largely from conflict and labeling-interactionist perspectives. Both assume that relations of inequality and disadvantage in the wider society will be reproduced and reenacted, and perhaps amplified, in the criminal court (for classical statements, see Schur 1971; Quinney 1974). Thus, the simple bypothesis of discrimination is that minority group members will experience harsher outcomes than do majority group members. Today, that hypothesis has been transformed to a context-dependent one as scholars argue for more sophisticated ways to detect and identify racial disparity. Such attempts to transform and reconfigure conflict and labeling-interactionist theories will continue to run into problems, however, without a better appreciation of how relations of race and ethnicity operate in criminal law and justice system processes.

One problem is an overly simplified dual model of majority-minority relations (i.e., advantaged/disadvantaged). How can a dual model be used to analyze the experiences of several racial and ethnic minority groups? Leiber's (1994) analysis of Native American, African American, and white youth at several stages of juvenile court process is instructive. He proposes that, while "Native Americans and African Americans are disproportionately two of the poorest, least educated, and most highly unemployed groups in the U.S. . . the conditions of Native Americans are described as the most appalling" (Leiber 1994, p. 260). Thus, Leiber takes the simple hypothesis of discrimination and heaps a second layer of disadvantage for Native Americans. But when he reviews the sparse literature on Native Americans and the justice system, he questions whether his assumption of double disadvantage is correct. He finds that "stereotypes associated with [Native Americans 
charged with] drug or alcohol offenses ... may affect the likelihood of receiving either harsher or more lenient outcomes" (p. 262), and he further suggests that African-American youth may be viewed as more "dangerous" in comparison to Native Americans. Specifying the direction of court leniency or harshness is not straightforward in a multiethnic frame (see also Hagan 1977).

For gender and sentencing, the simple hypothesis of discrimination is rarely used. Because bivariate outcomes show that women are "favored," the hypothesis that women's disadvantage in the wider society reproduces itself in the criminal court has not made sense. In its place have been several ad hoc efforts to explain apparent leniency toward women when it occurred: first came chivalry (Pollak 1950); then, judicial paternalism toward women (Nagel and Weitzman 1971). Next, perhaps to generate a sense of debate, Simon (1975) suggested that some women might be treated leniently and others harshly (or as "evil women") if they violated certain "sex-role stereotypes." Despite efforts to clarify the meaning of chivalry, paternalism, and evil women (see Moulds 1980; Nagel and Hagan 1983), these concepts lack an empirical referent and analytic bite.

Kruttschnitt (1980-81, 1982a, 1982b, 1984) and Kruttschnitt and Green (1984) developed more sophisticated arguments that drew from Black's (1976) ideas on law and social control. She suggested that, because women were more subject to informal social control in their lives than men (via their dependency on others or the state), they would be subject to less formal social control. Subsequent work by Daly (1987a, $1987 b, 1989 a, 1989 b$ ) outlined and tested a social control/social costs framework. Daly noted that, although Kruttschnitt's social control formulation explained variation in the treatment among men or women, it could not explain differential treatment between them; further, Daly argued that women's caretaking responsibility for others was the more crucial source of informal social control than their dependency on others. These arguments attempted to clarify how economic support and care for others could produce variable responses both among and between men and women. One as yet unsettled policy question is whether this family-based logic is acceptable.

More recent work by Steffensmeier, Kramer, and Streifel (1993) and Daly (1994a) centers on gender differences in the social organization of lawbreaking and criminal history, in addition to elements of women's past and present lives that, in comparison to men, make women appear to be less blameworthy, more conforming, and better prospects 
for reform. Apparent "sex effects" seen in previous studies can be viewed as arising from inadequate control variables and as warranted or explicable in light of court officials' consequentialist logic. In exploring the intersection of race and gender, Daly (1994a) found that black men stood out as the defendant group most at risk to receive the heaviest penalties. Their biographies were least likely to be constructed with a blurred boundaries theme of victimization and criminalization, they were most likely to be categorized as troublemakers or as committed to street life, and they were least likely to be seen as reformable.

The simple hypothesis of discrimination, founded on the dualism of advantaged-disadvantaged defendants, has proved unsatisfactory in understanding race, gender, and criminal process. Part of the problem is that the kinds of offenses subject to arrest and prosecution in state courts ensnare a predominantly disadvantaged population. To explain how court officials exercise discretion toward this already marginalized group requires a consideration of the cues and categories that officials use in assessing defendants' danger to others, of their conventionality and indispensability for families, and of their desire to change and "help themselves." A defendant's prior record, which is a powerful cue for officials in differentiating the amount of respect that defendants hold for the law and their degree of commitment to the "street life," may override individual circumstances that sometimes mitigate sentences.

Three broad modes of conceptualizing race and gender in criminal law and justice system practices have been adopted by social science and sociolegal scholars. These are law and practices as racist/sexist, white/male, and racialized/gendered (Daly [1994b], adapting in part from Smart [1992]). ${ }^{10}$ Virtually all empirical work on race and gender disparities (and our assessment of it) is framed within a racist/sexist perspective in that the research centers on whether sanctions are applied differently across varied racial-ethnic, gender groups. However, a new generation of feminist and critical race scholars has raised questions about the limits this conceptualization imposes on theory, research, and policy; they are more likely to embrace the latter two modes.

\footnotetext{
${ }^{10}$ Reiner (1993) and Smith (1994) discuss other ways of analyzing racial discrimination. Their comparison and ours is similar in emphasizing the limitations of individualbased models and the need to consider the disparate impact of law and policies on disadvantaged groups. Our analysis departs from theirs, however, in that they fail to address the different demands of justice that a joint consideration of race and gender raise.
} 


\section{A. Sexist/Racist Modes}

Analysts using a practices-as-racist-and-sexist perspective focus on ways of exposing differential treatment and eradicating it. Differential treatment is seen as synonymous with discrimination. The concern is that racial and ethnic minority group men and all women may be allocated fewer resources, may be judged by different standards, and may be denied opportunities. The corrective is "race-blind" and "genderblind" justice that treats all those before the court equally.

Critical race theorists challenge this position because, as they point out, racial dominance can be achieved in at least two ways: in an older form, by overtly racist practices, and in a newer form, by practices that are ostensibly race-neutral. As Cook (1992, p. 1007) explains, the former "predicate[s] subordination on difference," and the latter "predicate[s] subordination on sameness." Likewise, feminist legal theorists have criticized older, overtly sexist, and newer ostensibly genderneutral practices (MacKinnon 1987; Fineman 1991; Vogel 1993). Critical and feminist theorists are therefore more likely to adopt one of the other two conceptualizations. ${ }^{11}$

\section{B. White/Male Modes}

Practices-as-white-and-male proponents assume that the point of view of criminal law and justice system practices is white, middle-class, and male (Greene 1990, 1993; Roberts 1991; Austin 1992; Peller 1993). The precise elements of a "white point of view" (often referred to as "institutionalized racism") have not been clarified for justice system practices to the same extent that the "male point of view" has. One problem is that "whiteness" has both class and cultural dimensions. It includes notions of what constitutes appropriate dress, demeanor, ways of speaking, and child-rearing practices; it means believing that existing rules and authorities are legitimate and fair.

When practices-as-white-and-male proponents claim that law has a "point of view," the claim may be easily denied by law and its agents as outside the realm of acceptable legal discourse. That is because the claim undermines the principles on which law and normal science are built: objectivity and neutrality - the reputedly unbiased "view from nowhere" (Bordo 1990, p. 133). One way to reveal the "point of view" of law is to show that apparently neutral laws or practices can have a

\footnotetext{
${ }^{11}$ Liberal feminists would be more comfortable with the practices-as-racist-and-sexist formulation.
} 
disparate effect. Examples include the following: white/male justice cannot "hear" or empathize with stories of harm (Culp 1992; Daly 1994b); white/male justice overcriminalizes (the War on Drugs is a current example; see Tonry [1995, chap. 3] and discussion below); and white/male justice expects lawbreakers easily to conform to conventional behavior patterns and norms (Carlen 1988; Finnegan 1990; Austin 1992).

There are several problems with the justice-as-white-and-male position. First, it may be misleading to assume that white men "benefit or are celebrated in a rehearsal of practices that claim universality" (adapting from Smart [1992, p. 34]). Second, the argument may be unduly color-coding and gendering practices that are also linked to nation, culture, and class. Third, there are no coherent or unified conceptions of black, multiethnic, or feminist justice waiting in the wings to replace current laws and practices.

\section{Racialized/Gendered Modes}

The practices-as-racialized-and-gendered position assumes that race and gender relations structure criminal law and justice system practices so profoundly that legal subjects are saturated with racializing and gendered qualities. Majority group members do not always benefit, nor are women and minority group men always subordinated. Rather than analyzing race-ethnic or gender variability in justice system outcomes, the focus instead is on how race-ethnicity and gender are brought forth as racialized and gendered subject positions by criminal law and justice system practices. In taking this perspective, scholars analyze how criminal law and justice system practices may only be able to "see and think a gendered [and racialized] subject" (Smart 1992, p. 34).

One problem with the law-and-practices-as-racialized-and-gendered position is that it may produce knowledge that appears to be useless for changing policy or directing social change more generally. It is one thing to appreciate how people and texts are drenched in racialized and gendered codes and metaphors but quite another to know what to do with that knowledge. The position is important, however, for challenging the idea that race or gender are attached to people's bodies as a natural or stable characteristic (see Lubiano 1992). There is also an openness to seeing how minority group members can construct racialized and gendered identities that both subvert and confirm dominant group members' expectations.

While differences in theory and method may divide traditional and 
more critical sociolegal scholars, there is a shared interest in redressing patterns of racial and gender injustice. All three modes have strategic value, even if the first is the most practical and familiar for those in the policy world. For example, one may only be able to argue from a practices-as-racist position in a legal brief claiming discrimination against blacks in the imposition of the death penalty (Baldus, Woodworth, and Pulaski 1990, 1994). Legal arguments from a practices-as-male position can be effective, however, in challenging the presumptively "gender-free world" of the federal sentencing guidelines (Raeder 1993), and analyses from a practices-as-racialized-and-gendered position reveal that gender (and race) relations are constitutive of law (Smart 1989). Empirical studies of race and gender in the criminal process, which are typically framed within the racist/sexist mode, could be more effective by revealing the point of view of criminal law and justice system practices, including the disparate effect of particular laws and policies.

\section{Race and Gender Politics in Sentencing Reform}

Although in the previous section we used race/gender as an analogous couplet, the histories and logics of the social relations themselves differ. Before drawing out the implications of that point for sentencing reform, we discuss how black feminist scholars have theorized the race/gender relation. ${ }^{12}$

\section{A. Black Feminist Cballenges}

One classic black feminist reaction to the literary and historical literature of the 1960s and 1970s sets the stage: "All the women are white, all the blacks are men, but some of us are brave" (Hull, Scott, and Smith 1980). The point is that separate theorizing "about race" or "about gender" does not resonate with the history or experiences of black women. The second and perhaps more crucial point is that white people are racialized, and men, gendered. Thus, while "blacks" and "women" are marked as being on the subordinate side of race and gender relations, there is more to race and gender than a discussion of its subordinated members (see, e.g., Frankenberg [1993] on whiteness and Jefferson [1994] and Messerschmidt [1993] on masculinity). In particular, many black feminists named a theoretical construct of class-race-

${ }^{12}$ Black feminist scholarship in the United States and elsewhere is prodigious, although little of it has moved into criminology (for reviews, see Rice 1990; Daly 1993; Daly and Stephens 1995). 
gender to argue that these three relations were connected and intersecting, and unless all were considered, an understanding of inequality was incomplete (see, e.g., Crenshaw 1989; Collins 1990; hooks 1990).

From a black feminist perspective, the ways that sentencing reform has been discussed will invite the refrain "but some of us are brave." When sentencing reformers discuss race, they invariably focus on white and racial-ethnic minority group men. When they discuss gender, they do not differentiate by race or ethnicity.

\section{B. Sentencing Reform}

As race and gender politics unfolded in sentencing reform, race was structured by presumptive masculinity, and gender, when it was discussed, was nonracialized. American sentencing reform in the 1970 s was spawned by and wholly constructed through a race- (and, to some degree, class-) based politics. When women entered the frame, sentencing reformers were hemmed in by a "strong equality" stance that had emerged from these politics.

A partial and highly schematic history of punishment in the United States would go this way. In the last quarter of the nineteenth century, an optimistic rehabilitation-oriented ethos emerged based on individualized treatment and a forward-looking approach to punishment. Indeterminate sentences allowed for discretion by judges, probation officers, and parole boards to decide whether and when individuals were reformed or not a threat to community safety. These practices became politicized in the late 1960s. Of concern were apparent abuses of state officials' powers of arrest, prosecution, and sentencing; class-based disparities in criminal law; and racial disparities in sentences received and time spent incarcerated. Radical and liberal commentators called for limits on officials' discretionary power and, in sentencing, a shift away from the highly individualized model to stronger versions of equality and equal treatment. The call for change was interpreted by state legislatures, sentencing commissions, and a National Academy of Science panel (Blumstein et al. 1983) as a call for justice systems explicitly to abjure race- or class-linked factors such as employment status or familial situation as sentencing criteria.

From the initial premise that race- (and to a lesser degree, class-) linked factors should not be allowed to affect decisions in prejudicial ways, it was an easy slide to say that the focus of punishment ought to be the act, not the actor. That was the move to just deserts, which 
promised a measure of equal treatment for those committing like offenses. That policy, along with other nondesert approaches (such as mandatory minimums), were established during the $1970 \mathrm{~s}$ and $1980 \mathrm{~s}$ within a general context of a rising tide of punitiveness.

This demand for strong versions of equality in justice systems resonated with how racial justice has been conceived historically in U.S. liberal law: "equal justice under the law." Initially embodied in the three Reconstruction Amendments in the late 1860 s, the racial justice demand was keyed to black men (for the Fourteenth and Fifteenth Amendments, though not the Thirteenth). However, when women (or gender difference) are discussed (then and today), the justice demand shifts to a more weakened equality standard and a greater acceptance of difference. ${ }^{13}$ More specifically, in crime and justice, it has been easier to discuss differences in the kinds and qualities of crimes that men and women commit and in the kinds of justice system responses that may be more appropriate for women than it is to discuss differences ordered by race or ethnicity. As but one example, reformatories and prisons were expressly built for men and for women, but not for whites and blacks.

What happened then when sentencing reformers considered women in sentencing policy? As enumerated by Blumstein et al. (1983, p. 114), if the aim was to "equalize sentences," there were these options: to punish women more like men, to punish men more like women, or to shift both groups to achieve an average of past sentencing practices (split-the-difference). Of these, only one-to punish men more like women-optimally combines principles of parsimony and proportionality. That option was not acceptable at the time: it would have made the sentencing system appear "too lenient." Instead, sentencing reformers decided that if strong versions of equality were to be applied to men, then they should also be applied to women. In practical terms, this meant that black men should be punished no more than white men for "like crimes" and that all women would face harsher penalties (like men's or split the difference) than before.

${ }^{13}$ These different justice demands are evident in the U.S. Supreme Court's use of different standards in deciding whether sex- or race-based classifications in work, education, housing, voting, etc., are constitutional, although these have not been applied to criminal justice policy except in challenges to the death penalty. Sex-based classifications have been permitted a more relaxed standard (intermediate scrutiny) than have racebased classifications (strict scrutiny). We agree with Rhode's (1987, p. 21) observation that less attention should be given to "women's and minorities' respective places in an oppression sweepstakes" and more to "the continuities and discontinuities in various patterns of discrimination." 
An ironic result of sentencing reform is that in the name of a restricted notion of equality with men, more women (especially black women) are being incarcerated than ever before. And in the name of racial justice in the criminal process, more black men are being incarcerated than ever before. Sentencing reformers vastly underestimated the electorate's susceptibility to law-and-order appeals and the harsher penalties imposed on (and served by) offenders.

\section{A Policy Dilemma}

Were we advocates on behalf of disadvantaged groups of accused men, especially those who are members of racial and ethnic minority groups, we might endorse a strong version of equality in sentencing, perhaps with some allowance for their "good works" as fathers or community members (see Tonry 1995). But were we policy advocates on behalf of all accused women, we would not endorse strong equality for several reasons. First, any equality model is bound to be malecentered, taking men's circumstances, motives, and actions as the norm for crime and punishment. Second, women generally have more to gain from an individualized model, which focuses on future-oriented criteria such as having responsibilities for others and reform potential.

Imagine now that we are advocates for both groups. We find ourselves looking in two directions at the same time: toward seeing justice as equality (or "equal treatment"), on the one hand, and seeing justice as a response to individual (though often gender-linked) differences, on the other. Sentencing reformers faced this dilemma, and they decided to apply the distinctive demands of racial justice and racial redress to those for gender. That stance, coupled with the War on Drugs and the law-and-order campaigns of the 1980s, has yielded dramatically increasing incarceration rates.

\section{Recommendations for Policy and Future Research}

How should policy makers respond? How might they think differently about sentencing? We offer these recommendations for policy and future research.

First, policy makers need to rethink the aims and purposes of punishment. One way to do that is to contemplate women as sentencing subjects. As an initial step, we might imagine a form of gender neutrality that is female-normed, and we might fashion an equal treatment punishment scheme in which women, not men, are the standard. For 
example, if statistical averages of previous sentencing outcomes are used to guide future sentencing policy, policy makers should consider using women's, not men's, outcomes as the base. Research is needed that examines the varied circumstances and contexts of women's lawbreaking and the points at which they are both similar and different from men's lawbreaking. Variation in women's responses to sanctions or the threat of sanctions also need to be studied. We know that, on average, women are less likely to be repeat offenders and to return to prison. This should matter in devising sanctions and in fashioning sentencing policy. By disrupting the image of men as presumptive sentencing subjects, we may see some men's lawbreaking in a different, perhaps more sympathetic light, and we can revisit questions of what is just and humane punishment.

Second, policy makers must consider ways of shifting public opinion away from extraordinarily harsh punishment schemes. For two decades in the United States, there has been unremitting pressure for increases in penalties and no pressure for decreases. Liberals and radicals who were involved in the early sentencing reform movement envisaged not only a more equitable sentencing policy but one that reduced the use of incarceration as a crime control measure. However, the punitive tide has continually risen since the mid-1970s. As a result, while there has been increasing fiscal and political support for expanding the criminal justice system, there has been less for education, housing, and social welfare. Research in other countries suggests that the U.S. criminal justice system is more punitive than elsewhere. Comparative research needs to be brought into the policy debates in the United States; in that way, decreases in levels of punishment will not be seen as concessions to soft-hearted liberals but, rather, as a more rational allocation of resources. Research on alternatives to the criminal justice system, including alternatives to incarceration, must document promising approaches with a strong visual and economic message to policy makers and citizens.

Third, policy makers must address the foreseeable distributive effects of policies. If these have a disparate effect on particular groups, the policies need to be rethought. One way to inspire such rethinking is the tool of rebuttable presumption. That is, unless disparate-effectcausing policies can be shown to achieve important public policy goals, the policies should be reconsidered. The most dramatic example of not considering the disparate-effect-causing effects of a particular criminal justice policy was the War on Drugs. Because visible drug dealing is 
found in inner city areas, it was foreseeable that tactical policies aimed at substantial arrests and incarceration of drug dealers would yield a sharp increase in the numbers of minority group prisoners. This might have been justifiable it there had been reason to expect that drug use or trafficking would diminish as a result, but there was little reason to believe those things would happen (Wilson 1990; Tonry 1995, chap. 3). There is an important role for research that can forecast the future distributive effects of policies, under varied conditions.

Fourth, researchers need to fashion better methods of assessing justice system practices. That will entail an understanding of how justice "gets done," including practitioners' understandings of the "right response" and ways to evaluate those activities that are empathetic and critical. The just deserts movement sought to reduce disparity in sentencing those convicted of "like crimes" and with similar criminal histories. In seeking to eradicate sources of decision makers' prejudice, such policies unwittingly removed the positive uses of their discretion. Legislating justice from a distance and not consulting closely with practitioners themselves were mistakes. Likewise, assessing justice from a distance and not paying close attention to how justice "gets done" are mistakes. Statistical evidence alone is not sufficient in evaluating sentencing practices, nor is recourse to celebrated cases of unjust decisions. A more complete measure of justice would contain a moral dimension, and it would permit oscillation between logicoscientific and narrative modes of reasoning (Daly 1994a, chaps. 1 and 12).

Finally, policy makers need to wrestle with the fact that practices that are race- and gender-neutral, as well as those that are overtly prejudiced, can produce injustice. Further, there is a need to consider the distinctive demands of justice that multiple inequalities-of class, raceethnicity, gender, and age-produce. A justice system that is based on an imperative of uniformity (or equal treatment) will produce injustice, as will one based on an imperative of individuality (or individualized treatment). Striking a balance between the two appears the only route, but in taking this tack, state authorities will be assailed for both lacking a standard and imposing just one standard. We should expect that the practices of doing justice will produce destabilization and incoherence. Better to acknowledge the limits of doing justice in an unequal society, even as one imagines a different world. In the interim, the principles that may best guide policy makers are responses that cause least harm and a parsimonious use of penal law and the machinery of criminal justice. 
R E F E R E N C ES

American Friends Service Committee. 1971. Struggle for fustice: A Report on Crime and Punishment in America. New York: Hill \& Wang.

Ang, Ien. 1995. " 'I'm a Feminist But . . .': 'Other' Women and Postnational Feminism." In Transitions, edited by Barbara Caine and Rosemary Pringle. St. Leonards, New South Wales: Allen \& Unwin.

Austin, Regina. 1992. "'The Black Community,' Its Lawbreakers, and a Politics of Identification." Southern California Law Review 65:1769-1817.

Baldus, David C., George Woodworth, and Charles A. Pulaski, Jr. 1990. Equal Fustice and the Death Penalty. Boston: Northeastern University Press.

. 1994. "Reflections on the 'Inevitability' of Racial Discrimination in Capital Sentencing and the 'Impossibility' of Its Prevention, Detection, and Correction." Washington and Lee Law Review 51(2):359-430.

Bickle, Gayle S., and Ruth D. Peterson. 1991. "The Impact of Gender-Based Family Roles in Criminal Sentencing." Social Problems 38(3):372-94.

Black, Donald. 1976. The Behavior of Law. New York: Academic Press.

Blumberg, Abraham. 1979. Criminal 7ustice: Issues and Ironies. 2d ed. New York: New Viewpoints.

Blumstein, Alfred. 1982. "On the Racial Disproportionality of United States' Prison Populations." Fournal of Criminal Law and Criminology 73:1259-81.

Blumstein, Alfred, Jacqueline Cohen, Susan E. Martin, and Michael H. Tonry, eds. 1983. Research on Sentencing: The Search for Reform. Vols. 1 and 2. Washington, D.C.: National Academy Press.

Bogan, Kathleen, and David Factor. 1995. "Oregon Guidelines 1989-1994." Overcrozvded Times 6(2):1, 13-15.

Boland, Barbara, Elizabeth Brady, Herbert Tyson, and John Bassler. 1983. The Prosecution of Felony Arrests, 1979. Washington, D.C.: Institute for Law and Social Policy.

Boland, Barbara, Catherine H. Conly, Paul Mahanna, Lynn Warner, and Ronald Sones. 1990. The Prosecution of Felony Arrests, 1987. Cambridge, Mass.: Abt Associates, Inc.

Bordo, Susan. 1990. "Feminism, Postmodernism, and Gender Scepticism." In Feminism/Postmodern, edited by Linda J. Nicolson. New York: Routledge.

Bridges, George S., and Gina Beretta. 1994. "Gender, Race, and Social Control: Toward an Understanding of Sex Disparities in Imprisonment." In Inequality, Crime, and Social Control, edited by George S. Bridges and Martha A. Myers. Boulder, Colo.: Westview Press.

Bureau of Justice Statistics. 1984. Sentencing Practices in 13 States. Washington, D.C.: U.S. Department of Justice, Bureau of Justice Statistics.

- 1987. Sentencing Outcomes in 28 Felony Courts, 1985. Washington, D.C.: U.S. Department of Justice, Bureau of Justice Statistics.

- 1989a. Felony Sentences in State Courts, 1986. Washington, D.C.: U.S. Department of Justice, Bureau of Justice Statistics.

. 1989b. Criminal Cases in Five States, 1983-86. Washington, D.C.: U.S. Department of Justice, Bureau of Justice Statistics.

. 1990. Profile of Felons Convicted in State Courts, 1986. Washington, D.C.: U.S. Department of Justice, Bureau of Justice Statistics. 
1991. Tracking Offenders, 1988. Washington, D.C.: U.S. Department of Justice, Bureau of Justice Statistics.

- 1992. Women in fail 1989. Washington, D.C.: U.S. Department of Justice, Bureau of Justice Statistics.

. 1993a. National fudicial Reporting Program, 1990. Washington, D.C.:

U.S. Department of Justice, Bureau of Justice Statistics. 1993b. Felony Sentences in State Courts, 1990. Washington, D.C.: U.S. Department of Justice, Bureau of Justice Statistics.

- 1993c. Felony Defendants in Large Urban Counties, 1990. Washington, D.C.: U.S. Department of Justice, Bureau of Justice Statistics.

—. 1994a. Prisoners in 1993. Washington, D.C.: U.S. Department of Justice, Bureau of Justice Statistics.

1994b. Women in Prison 1991. Washington, D.C.: U.S. Department of Justice, Bureau of Justice Statistics.

1994c. Tracking Offenders, 1990. Washington, D.C.: U.S. Department of Justice, Bureau of Justice Statistics.

. 1994d. Capital Punishment 1993. Washington, D.C.: U.S. Department of Justice, Bureau of Justice Statistics.

- 1995a. Prisoners in 1994. Washington, D.C.: U.S. Department of Justice, Bureau of Justice Statistics.

. 1995b. "State and Federal Prisons Report Record Growth during Last 12 Months." Press release, December 3. Washington, D.C.: U.S. Department of Justice, Bureau of Justice Statistics.

—. 1995c. Fails and Fail Inmates, 1993-94. Washington, D.C.: U.S. Department of Justice, Bureau of Justice Statistics.

- 1996. "Almost 1.6 Million Men and Women in the Nation's Prisons and Jails." Press release, August 18. Washington, D.C.: U.S. Department of Justice.

Carlen, Pat. 1988. Women, Crime and Poverty. Philadelphia: Open University Press.

Chesney-Lind, Meda. 1991. "Patriarchy, Prisons, and Jails: A Critical Look at Trends in Women's Incarceration." Prison Fournal 71(1):51-67.

Chilton, Roland, and Susan K. Datesman. 1987. "Gender, Race, and Crime: An Analysis of Urban Arrest Trends, 1960-1980." Gender and Society 1: 152-71.

Collins, Patricia Hill. 1990. Black Feminist Thougbt. London: Unwin Hyman.

Cook, Anthony E. 1992. "The Spiritual Movement towards Justice." University of Illinois Law Review, pp. 1007-20.

Crenshaw, Kimberele. 1989. "Demarginalizing the Intersection of Race and Sex: A Black Feminist Critique of Antidiscrimination Doctrine, Feminist Theory, and Antiracist Politics." University of Chicago Legal Forum, pp. 13967.

Culp, Jerome M. 1992. "You Can Take Them to Water but You Can't Make Them Drink: Black Legal Scholarship and White Legal Scholars." University of Illinois Law Review, pp. 1021-41.

Daly, Kathleen. 1987a. "Structure and Practice of Familial-Based Justice in a Criminal Court." Law and Society Review 21(2):267-90. 
1987b. "Discrimination in the Criminal Courts: Family, Gender, and the Problem of Equal Treatment." Social Forces 66(1):152-175.

__ 1989a. "Rethinking Judicial Paternalism: Gender, Work-Family Relations, and Sentencing." Gender and Society 3(1):9-36.

- 1989b. "Neither Conflict nor Labeling nor Paternalism Will Suffice: Intersections of Race, Ethnicity, Gender, and Family in Criminal Court Decisions." Crime and Delinquency 35(1):136-68.

- 1989c. "Gender and Varieties of White-Collar Crime." Criminology 27(4):769-94.

- 1992. "Women's Pathways to Felony Court: Feminist Theories of Lawbreaking and Problems of Representation." Southern California Review of Law and Women's Studies 2(1):11-52.

--. 1993. "Class-Race-Gender: Sloganeering in Search of Meaning." Social 7ustice 20(1-2):56-71.

-1994a. Gender, Crime, and Punishment. New Haven, Conn.: Yale University Press.

- 1994b. "Criminal Law and Justice System Practices as Racist, White, and Racialized." Washington and Lee Law Review 51:431-64.

-1995. "Gender and Sentencing: What We Know and Don't Know from Empirical Research." Federal Sentencing Reporter 8(3):163-68.

Daly, Kathleen, and Rebecca Bordt. 1995. "Sex Effects and Sentencing: A Review of the Statistical Literature." Fustice Quarterly 12(1):14377.

Daly, Kathleen, and Deborah J. Stephens. 1995. "The 'Dark Figure' of Criminology: Toward a Black and Multi-ethnic Feminist Agenda for Theory and Research." In Engendering Criminology: International Feminist Perspectives on the Transformation of a Social Science, edited by Frances Heidensohn and Nicole Rafter. Milton Keynes: Open University Press.

Daly, Martin, and Margo Wilson. 1987. Homicide. New York: Aldine de Gruyter.

Eaton, Mary. 1986. Fustice for Women? Philadelphia: Open University Press.

Eisenstein, James, and Herbert Jacob. 1977. Felony fustice: An Organizational Analysis of Criminal Courts. Boston: Little, Brown.

Federal Bureau of Investigation. 1976. Crime in the United States-1975. Washington, D.C.: U.S. Government Printing Office.

- 1981. Crime in the United States-1980. Washington, D.C.: U.S. Government Printing Office.

- 1991. Crime in the United States-1990. Washington, D.C.: U.S. Government Printing Office.

-1995. Crime in the United States-1994. Washington, D.C.: U.S. Government Printing Office.

Federal Sentencing Reporter. 1995. "Thematic Issue: Gender and Sentencing." Vol. 8, no. 3 .

Feeley, Malcolm M. 1979. The Process Is the Punishment. New York: Russell Sage.

Fineman, Martha. 1991. The Illusion of Equality. Chicago: University of Chicago Press. 
Finnegan, William. 1990. "Out There." New Yorker, pt. 1 (September 10), pp. 51 ff., and pt. 2 (September 17), pp. $60 \mathrm{ff}$.

Frankenberg, Ruth. 1993. White Woman, Race Matters. Minneapolis: University of Minnesota Press.

Garland, David. 1990. Punishment and Modern Society. Chicago: University of Chicago Press.

- 1991. "Sociological Perspectives on Punishment." In Crime and fustice: A Review of Research, vol. 14, edited by Michael Tonry. Chicago: University of Chicago Press.

Gatens, Moira. 1996. Imaginary Bodies: Ethics, Power, and Corporeality, chap. 1. New York: Routledge.

Georges-Abeyie, Daniel E. 1989. "Race, Ethnicity, and the Spatial Dynamic: Toward a Realistic Study of Black Crime, Crime Victimization, and Criminal Justice Processing of Blacks." Social Fustice 16:35-54.

Greene, Dwight L. 1990. "Drug Decriminalization: A Chorus in Need of Masterrap's Voice.” Hofstra Law Review 18:457-500.

- 1993. "Justice Scalia and Tonto, Judicial Pluralistic Ignorance, and the Myth of Colorless Individualism in Bostick v. Florida." Tulane Law Review 67:1979-2062.

Gruhl, John, Susan Welch, and Cassia Spohn. 1984. "Women as Criminal Defendants: A Test for Paternalism." Western Political Quarterly 37:45667.

Hagan, John. 1977. "Finding 'Discrimination': A Question of Meaning." Ethnicity 4:167-76.

Hagan, John, and Kristin Bumiller. 1983. "Making Sense of Sentencing: A Review and Critique of Sentencing Research." In Research on Sentencing: The Search for Reform, vol. 2, edited by Alfred Blumstein, Jacqueline Cohen, Susan E. Martin, and Michael H. Tonry. Washington D.C.: National Academy Press.

Hall, Stuart. 1992. "What Is This 'Black' in Black Popular Culture?” In Black Popular Culture, edited by Gina Dent. Seattle: Bay Press.

Harris, Anthony R., and Lisa R. Meidling. 1994. "Criminal Behavior: Race and Class." In Criminology, 2d ed., edited by Joseph F. Sheley. Belmont, Calif.: Wadsworth.

Hawkins, Keith. 1986. "On Legal Decision-Making." Wasbington and Lee Law Review 43(4):1161-242.

Hill, Gary D., and Elizabeth M. Crawford. 1990. "Women, Race and Crime." Criminology 28:601-26.

hooks, bell. 1990. Yearning: Race, Gender, and Cultural Politics. Boston: South End Press.

Howe, Adrian. 1990. "Prologue to a History of Women's Imprisonment: In Search of a Feminist Perspective." Social fustice 17(2):5-22.

- 1994. Punish and Critique: Towards a Feminist Analysis of Penality. New York: Routledge.

Hudson, Barbara A. 1996. Understanding Fustice. Bristol, Pa.: Open University Press.

Hull, Gloria T., Patricia Bell Scott, and Barbara Smith, eds. 1980. All the 
Women Are White, All the Blacks Are Men, but Some of Us Are Brave. Westbury, N.Y.: Feminist Press.

Jefferson, Tony. 1994. "Theorizing Masculine Subjectivity." In fust Boys Doing Business? edited by Tim Newburn and Elizabeth A. Stanko. New York: Routledge.

Jurik, Nancy C., and Peter Gregware. 1991. "A Method for Murder: The Study of Homicides by Women." In Perspectives on Social Problems, vol. 4, edited by James Holstein. Westport, Conn.: JAI.

Kempf, Kimberly L., and Roy L. Austin. 1986. "Older and More Recent Evidence on Racial Discrimination in Sentencing." Journal of Quantitative Criminology 2(1):29-48.

Kleck, Gary. 1981. "Racial Discrimination in Criminal Sentencing: A Critical Evaluation of the Evidence with Additional Evidence on the Death Penalty." American Sociological Review 46:783-805.

Klepper, Steven, Daniel Nagin, and Luke-Jon Tierney. 1983. "Discrimination in the Criminal Justice System: A Critical Appraisal of the Literature." In Research on Sentencing: The Searcb for Reform, vol. 2, edited by Alfred Blumstein, Jacqueline Cohen, Susan E. Martin, and Michael H. Tonry. Washington, D.C.: National Academy Press.

Knapp, Kay. 1984. The Impact of the Minnesota Sentencing Guidelines-Three Year Evaluation. St. Paul: Minnesota Sentencing Guidelines Commission.

Kruttschnitt, Candace. 1980-81. "Social Status and Sentences of Female Offenders." Law and Society Review 15:247-65.

—. 1982a. "Women, Crime, and Dependency." Criminology 19:495-513.

- 1982b. "Respectable Women and the Law." Sociological Quarterly 23: $221-34$.

-1984. "Sex and Criminal Court Dispositions: The Unresolved Controversy." Fournal of Researcb in Crime and Delinquency 21:213-32.

Kruttschnitt, Candace, and Donald E. Green. 1984. "The Sex-Sanctioning Issue: Is It History?" American Sociological Reviewv 49:541-51.

Lacey, Nicola. 1994. "Introduction: Making Sense of Criminal Justice." In Criminal 7ustice, edited by Nicola Lacey. New York: Oxford University Press.

Langan, Patrick. 1995. Personal communication with authors, January.

Laub, John H., and Joan M. McDermott. 1985. "An Analysis of Serious Crime by Young Black Women." Criminology 23:81-98.

Leiber, Michael J. 1994. "A Comparison of Juvenile Court Outcomes for Native Americans, African Americans, and Whites." Fustice Quarterly 11(2): 257-79.

Lewis, Diane. 1981. "Black Women Offenders and Criminal Justice: Some Theoretical Considerations." In Comparing Female and Male Offenders, edited by Marguerite Q. Warren. Beverly Hills, Calif.: Sage.

Lubiano, Wahneema. 1992. "Black Ladies, Welfare Queens, and State Minstrels: Ideological War by Narrative Means." In Race-ing fustice, Engendering Power: Essays on Anita Hill, Clarence Thomas, and the Construction of Social Reality, edited by Toni Morrison. New York: Pantheon Books.

MacKinnon, Catharine. 1987. Feminism Unmodified. Cambridge, Mass.: Harvard University Press. 
MacLean, Brian D., and Dragan Milovanovic, eds. 1990. Racism, Empiricism, and Criminal Fustice. Vancouver: Collective Press.

Maguire, Kathleen, and Ann L. Pastore. 1994. Sourcebook of Criminal 7ustice Statistics-1993. Washington, D.C.: U.S. Department of Justice, Bureau of Justice Statistics.

Mann, Coramae Richey. 1984. "Race and Sentencing of Female Felons: A Field Study." International Journal of Women's Studies 7:160-72.

- 1993. Unequal Fustice: A Question of Color. Bloomington: Indiana University Press.

Martinez, Elizabeth. 1993. "Beyond Black/White: The Racisms of Our Time." Social fustice 20:22-34.

McDonald, Douglas C., and Kenneth E. Carlson. 1993. Sentencing in the Federal Courts: Does Race Matter? Washington, D.C.: U.S. Department of Justice.

Melossi, Dario. 1990. The State of Social Control: A Sociological Study of Concepts of State and Social Control in the Making of Democracy. Cambridge: Polity.

Melossi, Dario, and Massimo Pavarini. 1981. The Prison and the Factory: Origins of the Penitentiary System. Totowa, N.J.: Barnes \& Noble Books.

Meneses, Eloise Hiebert. 1994. "Race and Ethnicity: An Anthropological Perspective." Race, Sex and Class 1(2):137-46.

Messerschmidt, James W. 1993. Masculinities and Crime. Lanham, Md.: Rowman \& Littlefield.

Messinger, Sheldon, and Phillip Johnson. 1978. "California's Determinate Sentencing Laws." In Determinate Sentencing: Reform or Regression, edited by National Institute of Justice. Washington, D.C.: U.S. Government Printing Office.

Miethe, Terance D., and Charles A. Moore. 1985. "Socioeconomic Disparities under Determinate Sentencing Systems: A Comparison of Preguideline and Postguideline Practices in Minnesota." Criminology 23:337-63.

Moulds, Elizabeth. 1980. "Chivalry and Paternalism: Disparities of Treatment in the Criminal Justice System." Western Political Quarterly 31:416-30.

Myers, Martha. 1994. "The Courts: Prosecution and Sentencing." In Criminology, 2d ed., edited by Joseph F. Sheley. Belmont, Calif.: Wadsworth.

Myers, Samuel L., Jr. 1993. "Racial Disparities in Sentencing: Can Sentencing Reforms Reduce Discrimination in Punishment?" University of Colorado Law Review 64:781-808.

Nagel, Ilene, and John Hagan. 1983. "Gender and Crime: Offense Patterns and Criminal Court Sanctions." In Crime and fustice: An Annual Review of Research, vol. 4, edited by Michael Tonry and Norval Morris. Chicago: University of Chicago Press.

Nagel, Ilene H., and Barry L. Johnson. 1994. "The Role of Gender in a Structured Sentencing System: Equal Treatment, Policy Choices, and the Sentencing of Female Offenders under the United States Sentencing Guidelines." Fournal of Criminal Law and Criminology 85(1):181-221.

Nagel, Stuart, and Lenore Weitzman. 1971. "Women as Litigants." Hastings Law Journal 23:171-81.

Nardulli, Peter F., James Eisenstein, and Roy B. Flemming. 1988. The Tenor of Justice. Urbana: University of Illinois Press. 
Omi, Michael, and Howard Winant. 1994. Racial Formation in the United States. 2d ed. New York: Routledge.

Parent, Dale. 1988. Structuring Sentencing Discretion: The Evolution of Minnesota's Sentencing Guidelines. Stoneham, Mass.: Butterworth.

Parisi, Nicolette. 1982. "Are Females Treated Differently? A Review of the Theories and Evidence on Sentencing and Parole Decisions." In Fudge, Lawyer, Victim, Thief, edited by Nicole Hahn Rafter and Elizabeth Anne Stanko. Boston: Northeastern University Press.

Peller, Gary. 1993. "Criminal Law, Race, and the Ideology of Bias: Transcending the Critical Tools of the Sixties." Tulane Law Review 67:2231-52.

Polk, Kenneth, and D. Ranson. 1991. "Patterns of Homicide in Victoria." In Australian Violence: Contemporary Perspectives, edited by Duncan Chappell, Peter Grabosky, and Heather Strang. Canberra: Australian Institute of Criminology.

Pollak, Otto. 1950. The Criminality of Women. Philadelphia: University of Pennsylvania Press.

Quinney, Richard. 1974. Critique of Legal Order: Crime Control in Capitalist Society. Boston: Little, Brown.

Raeder, Myrna. 1993. "Gender and Sentencing: Single Moms, Battered Women, and Other Sex-Based Anomalies in the Gender Free World of the Federal Sentencing Guidelines." Pepperdine Law Reviezv 20(3):905-90.

Reiner, Robert. 1993. "Race, Crime and Justice: Models of Interpretation." In Minority Ethnic Groups in the Criminal fustice System, edited by Loraine R. Gelsthorpe. Cropwood Conference Series no. 21. Cambridge: Institute of Criminology.

Rhode, Deborah. 1987. "Justice, Gender, and the Justices." In Women, The Courts, and Equality, edited by Laura L. Crites and Winifred L. Hepperle. Newbury Park, Calif.: Sage.

Rice, Marcia. 1990. "Challenging Orthodoxies in Feminist Theory: A Black Feminist Critique." In Feminist Perspectives in Criminology, edited by Loraine Gelsthorpe and Allison Morris. Philadelphia: Open University Press.

Roberts, Dorothy E. 1991. "Punishing Drug Addicts Who Have Babies: Women of Color, Equality, and the Right of Privacy." Harvard Law Review 104:1419-82.

Roediger, David R. 1991. The Wages of Whiteness: Race and the Making of the American Working Class. London: Verso.

Schur, Edwin. 1971. Labeling Deviant Bebavior. New York: Harper \& Row.

Simon, Rita. 1975. Women and Crime. Lexington Mass.: Lexington Books.

Simpson, Sally S. 1991. "Caste, Class, and Violent Crime: Explaining Difference in Female Offending." Criminology 29:115-35.

Smart, Carol. 1989. Feminism and the Power of Law. New York: Routledge.

- 1992. "The Woman of Legal Discourse." Social and Legal Studies 1: 29-44.

Smith, David J. 1994. "Race, Crime, and Criminal Justice." In The Oxford Handbook of Criminology, edited by Mike Maguire, Rod Morgan, and Robert Reiner. Oxford: Clarendon Press. 
Smith, Douglas A., Christy Visher, and Laura Davidson. 1984. "Equity and Discretionary Justice: The Influence of Race on Police Arrest Decisions." Fournal of Criminal Law and Criminology 75:234-49.

Spohn, Cassia. 1994. "Race and Social Control." In Inequality, Crime, and Social Control, edited by George Bridges and Martha Myers. Boulder, Colo.: Westview.

Spohn, Cassia, Susan Welch, and John Gruhl. 1985. "Women Defendants in Court: The Interaction between Sex and Race in Convicting and Sentencing." Social Science Quarterly 66:178-85.

Steffensmeier, Darrell J. 1980. "Assessing the Impact of the Women's Movement on Sex-Based Differences in the Handling of Adult Criminal Defendants." Crime and Delinquency 26(3):344-57.

—. 1993. "National Trends in Female Arrests, 1960-1990: Assessment and Recommendations for Research." Journal of Quantitative Criminology 9(4):411-41.

- 1995. "Trends in Female Crime: It's Still a Man's World." In The Criminal 7ustice System and Women, 2d ed., edited by Barbara Raffel Price and Natalie J. Sokoloff. New York: McGraw-Hill.

Steffensmeier, Darrell, Emilie Allan, and Cathy Streifel. 1989. "Modernization and Female Crime: A Cross-National Test of Alternative Explanations." Social Forces 68:262-83.

Steffensmeier, Darrell, John Kramer, and Cathy Streifel. 1993. "Gender and Imprisonment Decisions." Criminology 31(3):411-46.

Takaki, Ronald. 1993. A Different Mirror: A History of Multicultural America. Boston: Little, Brown.

Tonry, Michael. 1995. Malign Neglect-Race, Crime, and Punishment in America. New York: Oxford.

Tonry, Michael, and Kathleen Hatlestad. 1997. Sentencing Reform in Overcrowded Times-a Comparative Perspective. New York: Oxford University Press.

U.S. Department of Commerce. 1996. Statistical Abstract of the United States1996. Washington, D.C.: U.S. Government Printing Office.

Visher, Christy. 1983. "Gender, Police Arrest Decisions, and Notions of Chivalry." Criminology 21:5-28.

Vogel, Lise. 1993. Mothers at Work: Maternity Policy in the U.S. Workplace. New Brunswick, N.J.: Rutgers University Press.

Wheeler, Stanton, Kenneth Mann, and Austin Sarat. 1988. Sitting in fudgment. New Haven, Conn.: Yale University Press.

Wilbanks, William. 1987. The Myth of a Racist Criminal Zustice System. Pacific Grove, Calif:: Brooks/Cole.

Wilson, James Q. 1990. "Drugs and Crime." In Drugs and Crime, edited by Michael Tonry and James Q. Wilson. Vol. 13 of Crime and Fustice: $A$ Review of Research, edited by Michael Tonry and Norval Morris. Chicago: University of Chicago Press.

Young, Vernetta. 1980. "Women, Race and Crime." Criminology 18:2634. 
Zatz, Marjorie S. 1984. "Race, Ethnicity, and Determinate Sentencing: A New Dimension to an Old Controversy." Criminology 22(2):147-71. 1985. "Pleas, Priors and Prison: Racial/Ethnic Differences in Sentencing." Social Science Research 14:169-93. 1987. "The Changing Forms of Racial/Ethnic Biases in Sentencing." fournal of Research in Crime and Delinquency 24(1):69-92. 